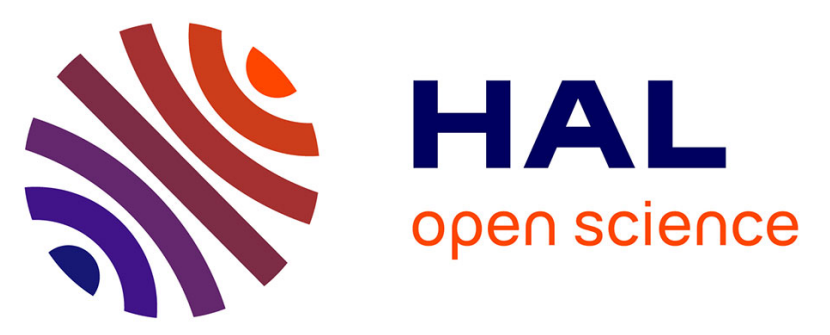

\title{
A non-heme diiron complex for (electro)catalytic reduction of dioxygen: tuning the selectivity through electron-delivery
}

Lianke Wang, Marcello Gennari, Fabián G. Cantú reinhard, Javier Gutiérrez, Adina Morozan, Christian Philouze, Serhiy Demeshko, Vincent Artero, Franc

Meyer, Sam P. de Visser, et al.

\section{To cite this version:}

Lianke Wang, Marcello Gennari, Fabián G. Cantú reinhard, Javier Gutiérrez, Adina Morozan, et al. A non-heme diiron complex for (electro)catalytic reduction of dioxygen: tuning the selectivity through electron-delivery. Journal of the American Chemical Society, 2019, 141 (20), pp.8244-8253. 10.1021/jacs.9b02011 . hal-02119043

\section{HAL Id: hal-02119043 \\ https://hal.science/hal-02119043}

Submitted on 24 Nov 2021

HAL is a multi-disciplinary open access archive for the deposit and dissemination of scientific research documents, whether they are published or not. The documents may come from teaching and research institutions in France or abroad, or from public or private research centers.
L'archive ouverte pluridisciplinaire HAL, est destinée au dépôt et à la diffusion de documents scientifiques de niveau recherche, publiés ou non, émanant des établissements d'enseignement et de recherche français ou étrangers, des laboratoires publics ou privés. 


\section{A Non-Heme Diiron Complex for (Electro)catalytic Reduction of Dioxygen}

DOI:

10.1021/jacs.9b02011

\section{Document Version}

Accepted author manuscript

Link to publication record in Manchester Research Explorer

\section{Citation for published version (APA):}

Wang, L., Gennari, M., Cantú Reinhard, F. G., Gutiérrez, J., Morozan, A., Philouze, C., Demeshko, S., Artero, V., Meyer, F., de Visser, S. P., \& Duboc, C. (2019). A Non-Heme Diiron Complex for (Electro)catalytic Reduction of Dioxygen: Tuning the Selectivity through Electron Delivery. Journal of the American Chemical Society, 141(20), 8244-8253. https://doi.org/10.1021/jacs.9b02011

\section{Published in:}

Journal of the American Chemical Society

\section{Citing this paper}

Please note that where the full-text provided on Manchester Research Explorer is the Author Accepted Manuscript or Proof version this may differ from the final Published version. If citing, it is advised that you check and use the publisher's definitive version.

\section{General rights}

Copyright and moral rights for the publications made accessible in the Research Explorer are retained by the authors and/or other copyright owners and it is a condition of accessing publications that users recognise and abide by the legal requirements associated with these rights.

\section{Takedown policy}

If you believe that this document breaches copyright please refer to the University of Manchester's Takedown Procedures [http://man.ac.uk/04Y6Bo] or contact uml.scholarlycommunications@manchester.ac.uk providing relevant details, so we can investigate your claim.

\section{OPEN ACCESS}




\title{
A non-heme diiron complex for (electro)catalytic reduction of dioxygen: tuning the selectivity through electron-delivery
}

Lianke Wang, ${ }^{\mathrm{a}}$ Marcello Gennari, ${ }^{\mathrm{a}, *}$ Fabián G. Cantú Reinhard, ${ }^{\mathrm{b}}$ Javier Gutierrez, ${ }^{a}$ Adina Morozan, ${ }^{\mathrm{c}}$ Christian Philouze, ${ }^{\mathrm{a}}$ Serhiy Demeshko, ${ }^{\mathrm{d}}$ Vincent Artero, ${ }^{\mathrm{c}}$ Franc Meyer, ${ }^{\mathrm{d}}$ Sam P. de Visser, ${ }^{\mathrm{b}, *}$ Carole Duboc ${ }^{\mathrm{a}, *}$

${ }^{a}$ Univ. Grenoble Alpes, CNRS UMR 5250, DCM, F-38000 Grenoble, France

${ }^{b}$ Manchester Institute of Biotechnology and School of Chemical Engineering and Analytical Science, The University of Manchester, 131 Princess Street, Manchester M1 7DN, United Kingdom

${ }^{c}$ Université Grenoble Alpes, CNRS, CEA, Laboratoire de Chimie et Biologie des Métaux, F38000 Grenoble, France

${ }^{d}$ Universität Göttingen, Institut für Anorganische Chemie, Tammannstrasse 4, D-37077

Göttingen, Germany

* corresponding authors: carole.duboc@univ-grenoble-alpes.fr; marcello.gennari@univgrenoble-alpes.fr; sam.devisser@manchester.ac.uk

\begin{abstract}
In the Oxygen Reduction Reaction (ORR) domain, the investigation of new homogeneous catalysts is a crucial step towards the full comprehension of the key structural and/or electronic factors that control catalytic efficiency and selectivity. Herein, we report a unique non-heme diiron complex that can act as a homogeneous ORR catalyst in acetonitrile solution. This iron(II)-thiolate dinuclear complex, $\left[\mathrm{Fe}_{2}{ }_{2}(\mathrm{LS})(\mathrm{LSH})\right]\left(\left[\mathrm{Fe}_{2}{ }^{\mathbf{S H}}\right]^{+}\right)\left(\mathrm{LS}^{2-}=2,2^{\prime}-\right.$ (2,2'-bipyridine-6,6'-diyl)bis(1,1-diphenylethanethiolate)) contains a thiol group in the metal coordination sphere. $\left[\mathrm{Fe}_{2}{ }^{\mathrm{SH}}\right]^{+}$is an efficient ORR catalyst both in the presence of a oneelectron reducing agent as well as under electrochemically assisted conditions. However, its selectivity is dependent on the electron delivery pathway, in particular, the process is selective for $\mathrm{H}_{2} \mathrm{O}_{2}$ production under chemical conditions (up to $\sim 95 \%$ ), whereas $\mathrm{H}_{2} \mathrm{O}$ is the main product during electrocatalysis (less than $\sim 10 \% \quad \mathrm{H}_{2} \mathrm{O}_{2}$ ). Based on computational work alongside the experimental data, a mechanistic proposal is discussed that rationalizes the selective and tunable reduction of dioxygen.
\end{abstract}




\section{Introduction}

The development of efficient, stable and noble metal-free catalysts for the $\mathrm{O}_{2}$ reduction reaction (ORR) with selective production of either water or hydrogen peroxide remains one of the central challenges in the energy conversion domain. ${ }^{1,2}$ Fuel cell design is focused on the production of electricity based on the four-electron $\mathrm{O}_{2}$ reduction (to $\mathrm{H}_{2} \mathrm{O}$ ) at the cathode, associated with the oxidation of a fuel (such as $\mathrm{H}_{2}$ or $\mathrm{MeOH}$ ) at the anode. ${ }^{3-5}$ On the other hand, the two-electron $\mathrm{O}_{2}$ reduction is an interesting strategy to produce $\mathrm{H}_{2} \mathrm{O}_{2}$, which represents a valuable commodity chemical and a versatile and clean oxidizing agent. ${ }^{6-8}$ Heterogeneous ORR catalysts have been mainly developed towards implementation into exploitable devices for such applications. ${ }^{9,10}$ Among them, the most promising noble metalfree materials are nitrogen-doped nanocarbon materials, containing molecularly-defined active sites based on metal porphyrinic moieties. ${ }^{11,12}$ Regarding molecular homogeneous catalysts, their study generally allows for a deeper comprehension of the ORR mechanism by identifying the rate limiting steps for the reaction and the key structural and electronic factors that control their activity and selectivity (two proton/two electron $v s$ four proton/four electron $\mathrm{O}_{2}$ reduction). ${ }^{1,13}$ Such investigation should eventually lead to enhanced efficiency through rational ligand design (e.g. by introduction of proton relays or Lewis acidic sites) for guiding the bifurcation processes into the wanted reaction channel.

Regarding homogeneous ORR catalysts, the most common and well-studied ones are based on iron or cobalt complexes embedded in macrocyclic heme-like ligands (such as porphyrins, phthalocyanines, or corroles). ${ }^{14-21}$ Detailed electrochemical studies of a series of such complexes evidenced how Fe-based catalysts are generally more selective for 4-electron $\mathrm{O}_{2}$ reduction than their Co analogues. ${ }^{1,13,22}$ This difference in reactivity is proposed to be a consequence of the generation of high-valent metal-oxo species that are easier to generate for hemes than for porphyrinic complexes based on other metal ions. Catalysts with non-heme ligands have been much less explored, although some studies on copper-based complexes ${ }^{23-30}$ and, to a lesser extent, manganese-based systems have been reported. ${ }^{31-34}$ Even though in several cases the nature of the acid and/or the presence of a proton relay was investigated on such systems, the selectivity towards $4 \mathrm{H}^{+} / 4 \mathrm{e}^{-}$vs $2 \mathrm{H}^{+} / 2 \mathrm{e}^{-}$ORR catalysis is still difficult to predict.

For homogeneous catalysts, generally two ways to provide electrons have been adopted, namely through the use of an appropriate reducing agent or an electrode (with application of a suitable electrochemical potential). Both approaches have been widely tested but rarely with the same catalyst. Using an Fe-based porphyrin system, Mayer et al. observed the same 
efficiency and comparable selectivities for $\mathrm{H}_{2} \mathrm{O}_{2}$ production for both the chemically- and electrochemically-driven processes $(10( \pm 3) \%$ vs $10-20 \%) .{ }^{35}$ A mononuclear $\mathrm{Cu}$ complex supported by a tetrapodal nitrogen-donor ligand was also reported and found to be selective for $4 \mathrm{H}^{+} / 4 \mathrm{e}^{-}$ORR catalysis in both cases. However, in that example electrocatalysis was performed in protic solvent, ${ }^{36}$ while chemical reduction was carried out in acetone and hence the environmental conditions affected the catalysis and selectivity. ${ }^{23}$

In the present work, we report the synthesis, characterization and reactivity of a dinuclear non-heme iron complex, $\left.\left[\mathrm{Fe}_{2}{ }_{2} \mathrm{ILS}\right)(\mathrm{LSH})\right]\left(\mathrm{LS}^{2-}=2,2^{\prime}\right.$-(2,2'-bipyridine-6,6'-diyl)bis(1,1diphenylethanethiolate), ${ }^{37}$ that acts as a homogeneous $\mathrm{O}_{2}$ reduction catalyst and displays a change in selectivity under chemical versus electrochemical conditions. The process is selective for $\mathrm{H}_{2} \mathrm{O}_{2}$ production when octamethylferrocene $\left(\mathrm{Me}_{8} \mathrm{Fc}\right)$ is used as reducing agent, whereas $\mathrm{H}_{2} \mathrm{O}$ is dominant when catalysis is driven electrochemically, while the other main experimental parameters (solvent, catalyst concentration, nature and concentration of the acid) remained unchanged. With the aim of understanding how the selectivity could be fine-tuned as a function of the different electron sources, a mechanistic investigation supported by theoretical calculations has been performed. Surprisingly, even though the iron-oxygen chemistry has been extensively investigated, ${ }^{38-44}$ our study reports the first non-heme ironbased ORR catalyst. In addition, it provides insights on how to control the ORR selectivity in separate pathways for 2-electron versus 4-electron reduction. Finally, comparison of the data gained in this work with those previously reported for the isostructural Mn complex ${ }^{32,45}$ allowed us to provide insights into the role of the transition metal in ORR catalysis mediated by such dimetallic complexes.

\section{Results}

Synthesis and solid-state properties of the dimercapto-bridged $\mathrm{Fe}^{\mathrm{II}}$ dinuclear complex. Under an inert atmosphere the $\mathrm{LS}^{2-}$ ligand ${ }^{37}$ reacts with $\mathrm{Fe}\left(\mathrm{BF}_{4}\right)_{2} \bullet 6 \mathrm{H}_{2} \mathrm{O}$ (1.2 equiv.) in THF to yield a brown precipitate that was characterized as $\left[\mathrm{Fe}_{2}{ }_{2}^{\mathrm{II}} \mathrm{SH}^{+}\right.$or $\left[\mathrm{Fe}^{\mathrm{II}}(\mathrm{LS})(\mathrm{LSH})\right]^{+}$(Scheme 1). Single crystal X-ray diffraction data collected on the isolated product reveal a dimercaptobridged dinuclear $\mathrm{Fe}^{\mathrm{II}}$ complex $\left[\mathrm{Fe}^{\mathrm{II}}{ }_{2}(\mathrm{LS})(\mathrm{LSH})\right] \mathrm{BF}_{4}\left(\left[\mathbf{F e}_{2}{ }^{\mathbf{S H}^{+}}\right]^{+}\right.$, isostructural to the parent $\mathrm{Mn}^{\mathrm{II}}$ compound $\left(\left[\mathrm{Mn}_{2}{ }_{2}{ }^{\mathrm{II}}(\mathrm{LS})(\mathrm{LSH})\right] \mathrm{BF}_{4},\left[\mathbf{M n}_{2}{ }^{\mathbf{S H}}\right]^{+}\right.$reported previously. ${ }^{32}$ 


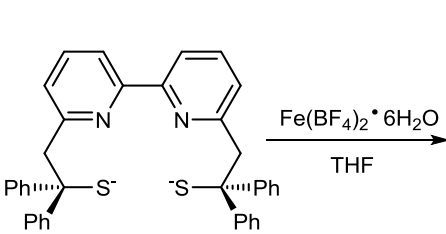

$\mathrm{LS}^{2-}$

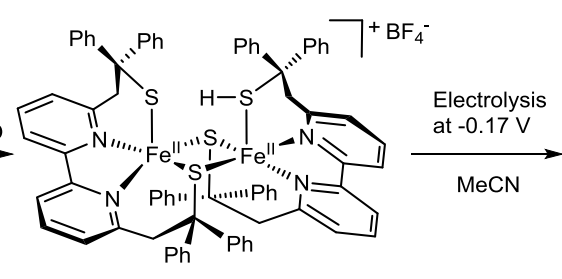

$\left[\mathrm{Fe}_{2} \mathrm{SH}^{+}\right.$

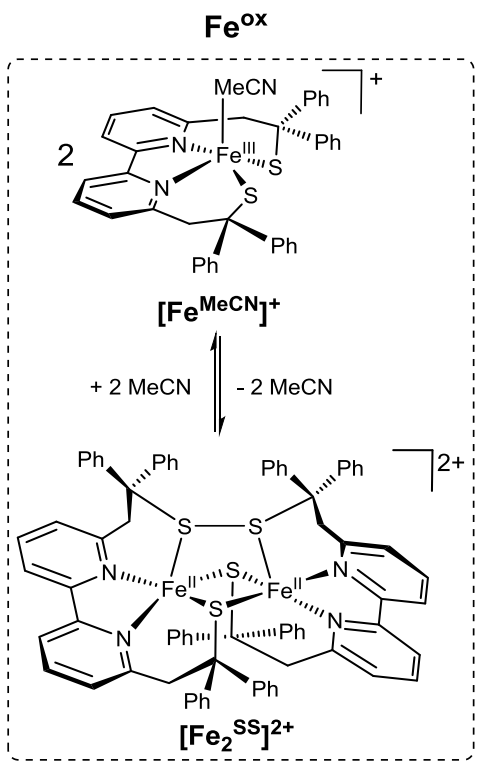

Scheme 1. Synthetic routes for the different iron-thiolate complexes described in this work.

Similarly to $\left[\mathbf{M n}_{\mathbf{2}}{ }^{\mathbf{S H}}\right]^{+}$, the structure of the $\left[\mathbf{F e}_{2}{ }^{\mathbf{S H}}\right]^{+}$cation (shown in Figure 1a, selected bond distances and angles are reported in the Supporting Information) displays: (i) a planar $\left\{\mathrm{Fe}_{2} \mathrm{~S}_{2}\right\}$ diamond core with deviations from the Fe1S2Fe2S3 plane of $\sim 0.010 \AA$, (ii) two distinguishable metal sites, each $\mathrm{Fe}^{\mathrm{II}}$ center being pentacoordinated and surrounded by an $\mathrm{N} 2 \mathrm{~S} 3$ donor set in a distorted trigonal bipyramidal environment $\left(\tau_{5}=0.59\right.$ for Fe1 and $\tau_{5}=$ 0.68 for $\mathrm{Fe} 2),{ }^{46}$ (iii) no direct metal-metal interaction, with a metal 'metal distance of $3.1107(7) \AA$, and most importantly (iv) the unusual presence of one metal-bound thiol. ${ }^{47-50}$ The protonation of one thiolate is attested by the difference between the Fe1-S1 and Fe2-S4 bond lengths (2.3566(11) and 2.5387(11) $\AA$, respectively) that gives evidence of the protonation at S4. A similar $\sim 0.2 \AA$ discrepancy has been previously observed between the two Mn- $\mathrm{S}_{\text {terminal }}$ distances in $\left[\mathbf{M n}_{2}{ }^{\mathbf{S H}}\right]^{+}(\mathrm{Mn} 1-\mathrm{S} 1=2.4399(10) \AA$ and Mn2-S51 = 2.6462(10) $\AA$ ). Thiolate protonation in $\left[\mathbf{F e}_{2}{ }^{\mathbf{S H}}\right]^{+}$is further confirmed by significant electron density assigned to a hydrogen atom (H4) found on the difference Fourier map near S4 (S4 - H4 =

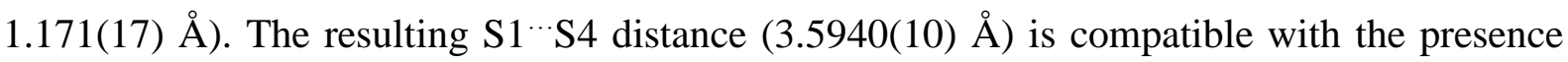
of an intramolecular S4-H4 ${ }^{\cdots} \mathrm{S} 1$ hydrogen-bond, while in the parent $\mathrm{Mn}$ complex the $\mathrm{S} \cdots \mathrm{S}$ distance is too long for such interaction $(3.772(3) \AA)$. 

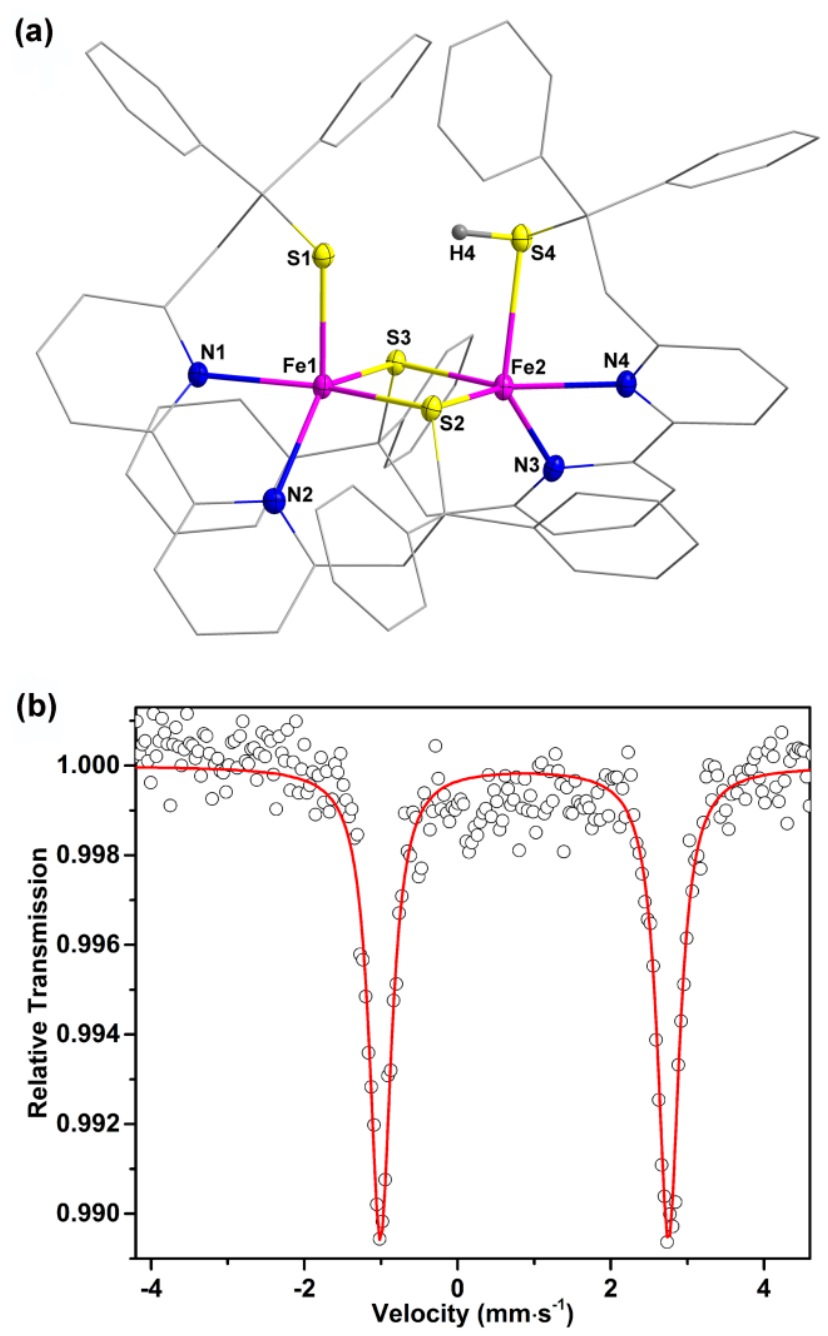

Figure 1. (a) Molecular structure of $\left[\mathrm{Fe}_{2}{ }^{\mathrm{SH}}\right] \mathrm{ClO}_{4} \bullet 1.5 \mathrm{MeCN} \bullet 0.5 \mathrm{Et}_{2} \mathrm{O}$ determined by X-ray crystallography with the thermal ellipsoids of the metal core drawn at 30\% probability level. All hydrogen atoms except $\mathrm{H} 4$, all anions and solvent molecules are omitted for clarity. (b) Solid-state zero-field Mössbauer spectrum of $\left[\mathrm{Fe}_{2}{ }^{\mathbf{S H}}\right]^{+}$recorded at $80 \mathrm{~K}$.

The +2 oxidation state of both Fe ions is confirmed by Mössbauer spectroscopy (Figure 1b): the zero-field spectrum of $\left[\mathrm{Fe}_{2}{ }^{\mathbf{S H}}\right]^{+}$recorded on a solid sample at $80 \mathrm{~K}$ displays a single doublet $\left(\delta=0.87 \mathrm{~mm}^{-1}\right.$ and $\left.\Delta E_{Q}=3.76 \mathrm{~mm}^{-1} \mathrm{~s}^{-1}\right)$ characteristic of two high-spin $(S=2) \mathrm{Fe}^{\mathrm{II}}$ ions. Taken together with the charge balance of the complex $(+1)$, these data are consistent with the presence of one Fe-bound thiol in $\left[\mathrm{Fe}_{2}{ }^{\mathbf{S H}}\right]^{+}$. The two Fe centers are indistinguishable by Mössbauer spectroscopy, reflecting the only small differences in their coordination spheres, and suggesting that elongation of one Fe-S bond does not significantly alter the metal ion's electronic structure. 
Solution and redox properties. In MeCN solution, $\left[\mathrm{Fe}_{2}{ }^{\mathbf{S H}}\right]^{+}$remains dinuclear, as indicated by (i) ESI-mass spectrometry, with a major peak at $1269.3 \mathrm{~m} / \mathrm{z}$ (with isotope pattern corresponding to $\left[\mathrm{Fe}_{2}{ }_{2}(\mathrm{LS})(\mathrm{LSH})\right]^{+}$; Figure S1) and the absence of any peak originating from mononuclear species, and (ii) the paramagnetic ${ }^{1} \mathrm{H}$ NMR spectrum of $\left[\mathbf{F e}_{2}{ }^{\mathbf{S H}}\right]^{+}$, displays no large paramagnetic shift as observed in the spectrum of the parent mononuclear complex $\left[\mathrm{Fe}^{\mathrm{II}}(\mathrm{LS}) \mathrm{Cl}\right]^{-51}$ (Figure S2), consistent with an antiferromagnetically coupled dinuclear high spin $\mathrm{Fe}^{\mathrm{II}}$ complex.

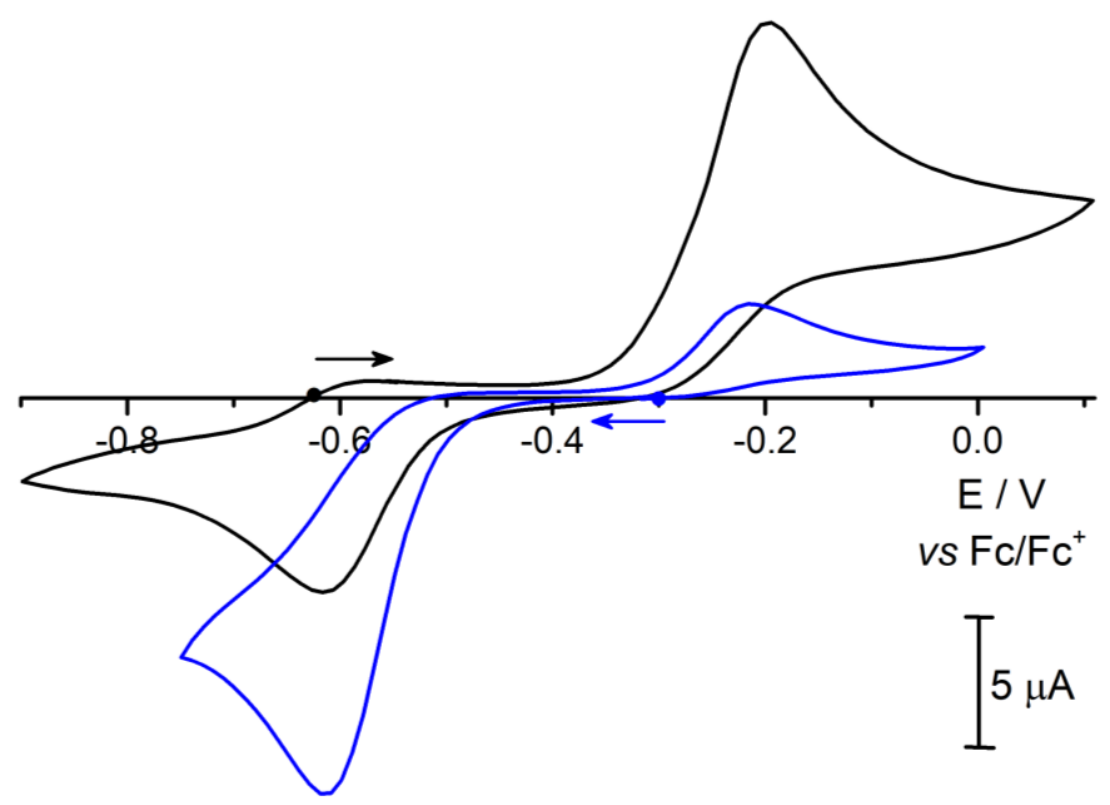

Figure 2. Cyclic voltammograms of $\left[\mathrm{Fe}_{2}{ }^{\mathrm{SH}}\right]^{+}(\sim 1.0 \mathrm{mM})$ before (black line) and after (blue line) bulk electrolysis at $-0.17 \mathrm{~V}$ vs $\mathrm{Fc}^{+} / \mathrm{Fc}$ in $\mathrm{MeCN}$ under argon atmosphere. Supporting electrolyte: $0.1 \mathrm{M} \mathrm{Bu}_{4} \mathrm{NClO}_{4}$, GC working electrode $(\varnothing=3 \mathrm{~mm})$, scan rate: $100 \mathrm{mV} \cdot \mathrm{s}^{-1}$.

The cyclic voltammogram $\left(\mathrm{CV}\right.$, Figure 2) of $\left[\mathrm{Fe}_{2}{ }^{\mathbf{S H}}\right]^{+}$displays an electrochemically irreversible oxidation step $\left(E \mathrm{p}_{\mathrm{a}}=-0.19 \mathrm{~V}\right.$ vs $\mathrm{Fc}^{+} / \mathrm{Fc}$ and $\left.E \mathrm{p}_{\mathrm{c}}=-0.63 \mathrm{~V}\right)$, which is partially reversible chemically $\left(i \mathrm{p}_{\mathrm{c}} / i \mathrm{p}_{\mathrm{a}} \sim 0.6\right)$. On the basis of coulometric and spectroscopic studies (vide infra), this redox system has been assigned to the two-electron metal-based oxidation of the dinuclear complex $\left(\mathrm{Fe}^{\mathrm{II}} \mathrm{Fe}^{\mathrm{II}} \rightarrow \mathrm{Fe}^{\mathrm{III}} \mathrm{Fe}^{\mathrm{III}}\right)$ followed by chemical rearrangements. A mixture of two different oxidized species is generated by bulk electrolysis carried out at $-0.17 \mathrm{~V}$ vs $\mathrm{Fc}^{+} / \mathrm{Fc}$ of a MeCN solution of $\left[\mathrm{Fe}_{2}{ }^{\mathbf{S H}}\right]^{+}(6.65 \mathrm{C}$ of charge passed for $0.0368 \mathrm{mmol}$ of initial complex, corresponding to 0.94 electrons per Fe atom). By different spectroscopic techniques (including UV-vis, ${ }^{1} \mathrm{H}$-NMR, and $\mathrm{cw}$ X-band EPR), they have been identified ${ }^{52}$ as: (i) a mononuclear $\mathrm{Fe}^{\mathrm{III}}$-thiolate complex, $\left[\mathrm{Fe}^{\mathrm{III}}(\mathrm{LS})(\mathrm{MeCN})\right]^{+}\left(\left[\mathrm{Fe}^{\mathrm{MeCN}}\right]^{+}\right)$, and (ii) a dinuclear $\mathrm{Fe}^{\mathrm{II}}-$ 
disulfide complex, $\left[\mathrm{Fe}_{2}{ }_{2}(\mathrm{LSSL})\right]^{2+}\left(\left[\mathrm{Fe}_{2}{ }^{\mathrm{SS}}\right]^{2+}, \mathrm{LSSL}^{2-}=\right.$ disulfide form of the $\mathrm{LS}^{2-}$ ligand, Scheme 1). This assignment relies on our previous investigation showing that an identical mixture is obtained when $\left[\mathbf{F e}_{2}{ }^{\mathbf{S s}}\right]^{2+}$ is dissolved in $\mathrm{MeCN}$. Note that in solid state, $\mathbf{F e}^{\mathbf{o x}}$ can be isolated in the dimeric form, $\left[\mathbf{F e}_{2}{ }^{\mathbf{S S}}\right]^{2+}{ }^{52}$ For simplicity, in the following paragraphs the $\left[\mathrm{Fe}^{\mathrm{MeCN}}\right]^{+}+\left[\mathrm{Fe}_{2}{ }^{\mathrm{SS}}\right]^{2+}$ mixture $(\sim 2: 1 \text { ratio })^{52}$ is designated $\mathbf{F e}^{\mathbf{o x}}$. Taken together, these results imply that fast deprotonation accompanies the double electron transfer before the $\mathbf{F e}^{\mathbf{o x}}$ complex is formed.

A similar redox behavior is observed for the parent Mn-based dinuclear complex $\left[\mathbf{M n}_{2}{ }^{\mathbf{S H}}\right]^{+}$, which displays a $\sim 180 \mathrm{mV}$ anodic shift for the $\mathrm{M}_{2}{ }^{\mathrm{II}} / \mathrm{M}_{2}{ }^{\mathrm{III}}$ redox system with respect to the $\mathrm{Fe}$ complex $\left(E \mathrm{p}_{\mathrm{a}}=-0.19 \mathrm{~V}\right.$ for Fe vs $E \mathrm{p}_{\mathrm{a}}=-0.01 \mathrm{~V}$ for $\left.\mathrm{Mn}\right){ }^{32,45}$ This shift indicates that $\left[\mathbf{F e}_{2}{ }^{\mathbf{S H}^{+}}\right]^{+}$ is expected to be more easily oxidized by dioxygen with respect to the corresponding $\mathrm{Mn}$ complex. For a previously described series of mononuclear $\mathrm{M}^{\mathrm{II}}$-thiolate complexes, an even larger cathodic shift $(290 \mathrm{mV})$ was observed between the Fe and Mn derivatives. ${ }^{53}$

Homogeneous catalysis and electrocatalysis for dioxygen reduction. The capability of $\mathbf{F e}^{\mathbf{o x}}$ and $\left[\mathrm{Fe}_{2}{ }^{\mathrm{SH}}\right]^{+}$to catalyze ORR was investigated in MeCN solution, in the presence of protons and electrons. The 2,6-lutidinium tetrafluoroborate acid $\left(\mathrm{LutHBF}_{4}\right)$ was employed as proton source, whereas electrons were delivered by a chemical reducing agent (octamethylferrocene, $\mathrm{Me}_{8} \mathrm{Fc}, E_{1 / 2}=-0.41 \mathrm{~V}$ vs $\mathrm{Fc}^{+} / \mathrm{Fc}$, Figure S11) or alternatively by applying an adequate electrochemical potential to a glassy carbon electrode. In the presence of $\mathrm{LutH}^{+},\left[\mathbf{F e}_{\mathbf{2}} \mathbf{S H}^{+}\right.$ reacts with $\mathrm{O}_{2}$ to generate $\mathbf{F e}^{\mathbf{o x}}$ (Figure S3). Note that this complex can also be prepared by bulk electrolysis of $\left[\mathbf{F e}_{2}{ }^{\mathbf{S H}}\right]^{+}$(see above), or by dissolving the $\left[\mathbf{F e}_{\mathbf{2}}{ }^{\mathbf{S S}}\right]\left(\mathrm{ClO}_{4}\right)_{2}$ solid in $\mathrm{MeCN}{ }^{51}$ Despite the fact that the redox potential of the $\mathrm{Me}_{8} \mathrm{Fc}^{+} / \mathrm{Me}_{8} \mathrm{Fc}$ couple is too high to reduce $\mathbf{F e}^{\mathbf{o x}}\left(E \mathrm{p}_{\mathrm{c}}=-0.63 \mathrm{~V}\right.$, see above $), \mathbf{F e}^{\mathbf{o x}}$ is efficiently reduced by $\mathrm{Me}_{8} \mathrm{Fc}$ in the presence of a large excess (50 and 150 equiv.) of $\mathrm{LutH}^{+}$to generate the oxygen reactive $\left[\mathrm{Fe}_{2}{ }^{\mathrm{SH}}\right]^{+}$species (see the UV-vis experiment in Figure S4). As expected, in the absence of protons, no reaction is observed by mixing $\mathbf{F e}^{\mathbf{o x}}$ and $\mathrm{Me}_{8} \mathrm{Fc}$ in $\mathrm{MeCN}$ solution under $\mathrm{Ar}$ atmosphere. The protonation step that occurs after the reduction of $\mathbf{F e}^{\mathbf{o x}}$ to generate $\left[\mathbf{F e}_{\mathbf{2}}{ }^{\mathbf{S H}}\right]^{+}$is therefore proposed to trigger the electron transfer process (sequential proton coupled electron transfer, PCET). Accordingly, in the $\mathrm{CV}$ of $\mathbf{F e}^{\mathbf{o x}}$ the cathodic wave is $60 \mathrm{mV}$ shifted to a less negative potential $\left(E \mathrm{p}_{\mathrm{c}}=-0.57 \mathrm{~V}\right)$ after the addition of 150 equiv. of $\mathrm{LutH}^{+}$(Figure S12).

As revealed by UV-vis absorption monitoring (Figure 3a, Table S3), the addition of a catalytic amount of $\mathbf{F e}^{\mathbf{o x}}(100 \mu \mathrm{M})$ to an air-saturated $\left(\sim 1.6 \mathrm{mMatm}^{-1} \mathrm{O}_{2}\right) \mathrm{MeCN}$ solution of $\mathrm{Me}_{8} \mathrm{Fc}$ ( $2 \mathrm{mM}, 20$ equiv.) and $\mathrm{LutH}^{+}(15 \mathrm{mM}, 150$ equiv.) results in the progressive oxidation 
of $\mathrm{Me}_{8} \mathrm{Fc}$ to $\mathrm{Me}_{8} \mathrm{Fc}^{+}\left(\lambda_{\max }=750 \mathrm{~nm}, \varepsilon=420 \mathrm{M}^{-1} \mathrm{~cm}^{-1}\right)$, up to a $\sim 75( \pm 10) \%$ amount. A similar behaviour is observed when $\left[\mathrm{Fe}_{2}{ }^{\mathrm{SH}}\right]^{+}$is employed as ORR catalyst (Figure S5), indicating that both species are involved in the same catalytic cycle. In the absence of catalyst (and on the timescale of catalysis) $\mathrm{Me}_{8} \mathrm{Fc}$ is not oxidized by $\mathrm{O}_{2}$. The absence of catalysis when the $\mathrm{Fe}$ complexes $\left[\mathrm{Fe}\left(\mathrm{H}_{2} \mathrm{O}\right)_{6}\right]\left(\mathrm{BF}_{4}\right)_{2}$ or $\left[\mathrm{Fe}(\mathrm{bpy})_{3}\right]\left(\mathrm{PF}_{6}\right)_{2}$ are employed, highlights the remarkable beneficial effect of the coordination sphere provided by the thiolate-rich $\mathrm{LS}^{2-}$ ligand. The nonquantitative $\mathrm{Me}_{8} \mathrm{Fc}$ oxidation in the presence of $\mathbf{F e}^{\mathbf{o x}}$ or $\left[\mathrm{Fe}_{2}{ }^{\mathrm{SH}}\right]^{+}$can be rationalized in term of partial catalyst deactivation during the ORR, most likely because of sulfur oxygenation in the presence of in-situ generated $\mathrm{H}_{2} \mathrm{O}_{2}$ (Figure S9).

The amount of hydrogen peroxide produced in the reaction solution during the ORR catalysis was quantified from a spectrophotometric assay using the Ti-TPyP reagent for the titration (see Table S3). ${ }^{54,55}$ In the presence of $\mathbf{F e}^{\mathbf{o x}}$ as catalyst, under the typical conditions of Figure 3, a $0.67( \pm 0.03) \mathrm{mM}$ concentration of $\mathrm{H}_{2} \mathrm{O}_{2}$ is detected after $10 \mathrm{~min}$. If we take into account the overall reaction stoichiometry (Eq. 1), this implies a $94( \pm 4) \%$ selectivity of the catalytic process for $\mathrm{H}_{2} \mathrm{O}_{2}$ production.

$$
\mathrm{O}_{2}+2 \mathrm{Me}_{8} \mathrm{Fc}+2 \mathrm{LutH}^{+} \rightarrow \mathrm{H}_{2} \mathrm{O}_{2}+2 \mathrm{Me}_{8} \mathrm{Fc}^{+}+2 \mathrm{Lut} \text { (Eq. 1) }
$$

Under these conditions, the ORR selectivity using $\mathbf{F e}^{\mathbf{o x}}$ is thus comparable to that measured with the parent Mn catalyst $(82( \pm 2) \%)$.

The kinetic profiles for the generation of $\mathrm{Me}_{8} \mathrm{Fc}^{+}$catalyzed by $\mathrm{Fe}^{\mathbf{0 x}}$ and the parent $\mathrm{Mn}$ catalyst $\left(\left[\mathbf{M n}_{2}{ }^{\mathbf{S H}^{+}}\right]^{+}\right)$(Figure S6) indicate one order of magnitude faster apparent kinetics for the iron system $\left(\mathrm{TOF}_{\mathrm{i}} \mathbf{F} \mathbf{e}^{\mathbf{o x}}=8( \pm 1) 10^{3} \mathrm{~h}^{-1}\right)$ compared to the manganese system $\left(\mathrm{TOF}_{\mathrm{i}}\left[\mathbf{M n}_{\mathbf{2}}{ }^{\mathbf{S H}}\right]^{+} \approx 4.0\right.$ $( \pm 0.4) \cdot 10^{2} \mathrm{~h}^{-1}, \mathrm{TOF}_{\mathrm{i}}=$ initial turnover frequency).

In the case of $\mathbf{F e}^{\mathbf{o x}}$, the $\mathrm{TOF}_{\mathrm{i}}$ is neither significantly sensitive to the relative concentration of acid (from 5 to $15 \mathrm{mM}$ ) nor of reductant (from 2 to $4 \mathrm{mM}$ ), but the selectivity for $\mathrm{H}_{2} \mathrm{O}_{2}$ drops when the concentration of reductant increases $\left(46( \pm 4) \%\right.$ with $4 \mathrm{mM}$ of $\mathrm{Me}_{8} \mathrm{Fc}$, Table S3). 

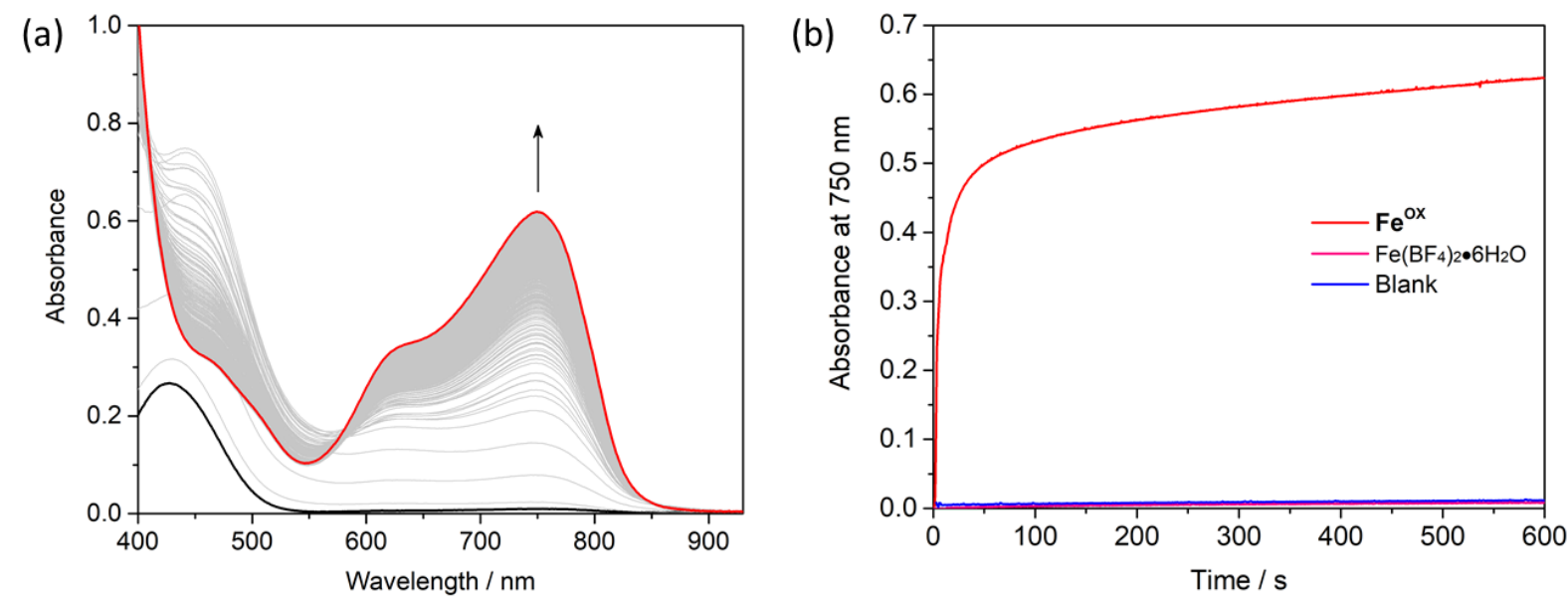

Figure 3. (a) UV-vis spectral changes observed during ORR catalyzed by $\mathbf{F e}^{\mathbf{0 x}}$ in the presence of $\mathrm{LutH}^{+}$and $\mathrm{Me}_{8} \mathrm{Fc}$ in $\mathrm{MeCN}$ at $293 \mathrm{~K}: 2.0 \mathrm{mM} \mathrm{Me}{ }_{8} \mathrm{Fc}, 15 \mathrm{mM} \mathrm{LutHBF}$, $0.1 \mathrm{mM}$ (dimer) $\mathbf{F e}^{\mathbf{0 x}}$, air-saturated solution, $1 \mathrm{~cm}$ path length, $\Delta t=0.5 \mathrm{~s}$. (b) Representative kinetic profiles for the formation of $\mathrm{Me}_{8} \mathrm{Fc}^{+}$at $750 \mathrm{~nm}$ in the presence of $\mathbf{F e}^{\mathbf{o x}}$ ([Fe $\left.{ }_{2}{ }^{\mathrm{SH}}\right]^{+}$in Figure S5), $\mathrm{Fe}\left(\mathrm{BF}_{4}\right)_{2} \bullet 6 \mathrm{H}_{2} \mathrm{O}$, or in the absence of catalyst (blank).

To test the ability of the air-stable $\mathbf{F e}^{\mathbf{o x}}$ catalyst to serve as ORR electrocatalyst, $\mathrm{CV}$ experiments of $\mathbf{F e}^{\mathbf{o x}}(0.1 \mathrm{mM})$ were performed in the presence of a buffered $\mathrm{LutH}^{+} / \mathrm{Lut} \mathrm{MeCN}$ solution (15 mM, 150 equiv.) under saturated argon (Figure S14a) or oxygen atmosphere (Figure 4a). Under $\mathrm{O}_{2}$ saturated atmosphere, an irreversible oxygen-reduction peak appears at $E_{\text {cat } / 2}=-0.50 \mathrm{~V}$ vs $\mathrm{Fc}^{+} / \mathrm{Fc}$ only in the presence of $\mathbf{F e}^{\mathbf{0 x}}$. The ORR peak onset is only slightly shifted (to less negative potentials) with respect to the cathodic peak of $\mathbf{F e}^{\mathbf{o x}}$ under $\mathrm{Ar}$ atmosphere $\left(E \mathrm{p}_{\mathrm{c}}=-0.60 \mathrm{~V}\right)$, but is $\sim 5$-fold more intense under the same experimental conditions (see Figure $4 \mathrm{a}$ vs Figure S14a). These data unequivocally demonstrate the electrocatalytic activity of $\mathbf{F e} e^{\mathbf{o x}}$ towards $\mathrm{O}_{2}$ reduction in MeCN solution. A rinse test confirms that the activity arises from the iron catalyst in solution and is not due to any electrodeadsorbed material (see Figure S13).

The standard potentials for $2 \mathrm{H}^{+} / 2 \mathrm{e}^{-}$and $4 \mathrm{H}^{+} / 4 \mathrm{e}^{-}$ORR can be estimated in the buffered $\mathrm{LutH}^{+} / \mathrm{Lut} \mathrm{MeCN}$ solution (lutidinium, $\mathrm{pK}_{\mathrm{a}}=13.92$ in $\left.\mathrm{MeCN}\right)^{56}: E^{0}\left(\mathrm{O}_{2}, 4 \mathrm{LutH}^{+} / 2 \mathrm{H}_{2} \mathrm{O}\right)=1.21$ - $0.0592 \mathrm{pK}_{\mathrm{a}} \approx 0.39 \mathrm{~V} v s \mathrm{Fc}^{+} / \mathrm{Fc}$, by using the method reported by Mayer et al., ${ }^{1,22}$ or $E^{0}\left(\mathrm{O}_{2}, 4 \mathrm{LutH}^{+} / 2 \mathrm{H}_{2} \mathrm{O}\right)=2.038-0.0592 \mathrm{pK}_{\mathrm{a}} \approx 1.21 \mathrm{~V} v s$ NHE, corresponding to $0.68 \mathrm{~V} v s$ $\mathrm{Fc}^{+} / \mathrm{Fc},{ }^{57}$ by using the method reported by Nocera et al. ${ }^{58} ; E^{0}\left(\mathrm{O}_{2}, 2 \mathrm{LutH}^{+} / \mathrm{H}_{2} \mathrm{O}_{2}\right)=0.68-$ $0.0592 \mathrm{pK}_{\mathrm{a}} \approx-0.14 \mathrm{~V} v s \mathrm{Fc}^{+} / \mathrm{Fc}$ (Mayer method). ${ }^{56}$ On the basis of the experimental mid-wave potential of the catalytic wave $\left(E_{\text {cat } / 2}=-0.50 \mathrm{~V} v s \mathrm{Fc}^{+} / \mathrm{Fc}\right)$, the $4 \mathrm{H}^{+} / 4 \mathrm{e}^{-} \mathrm{ORR}$ overpotential $\eta\left(\mathrm{O}_{2}, 4 \mathrm{LutH}^{+} / 2 \mathrm{H}_{2} \mathrm{O}\right)\left(\eta=E_{\text {cat } / 2} E^{0}\right)$ is estimated in the range $0.89-1.18 \mathrm{~V}$, while the $2 \mathrm{H}^{+} / 2 \mathrm{e}^{-}$ 
ORR overpotential $\eta\left(\mathrm{O}_{2}, 2 \mathrm{LutH}^{+} / \mathrm{H}_{2} \mathrm{O}_{2}\right.$ is determined to $0.36 \mathrm{~V}$. These values are typical for homogeneous $2 \mathrm{H}^{+} / 2 \mathrm{e}^{-}$and $4 \mathrm{H}^{+} / 4 \mathrm{e}^{-}$ORR metal catalysts. ${ }^{1,59}$

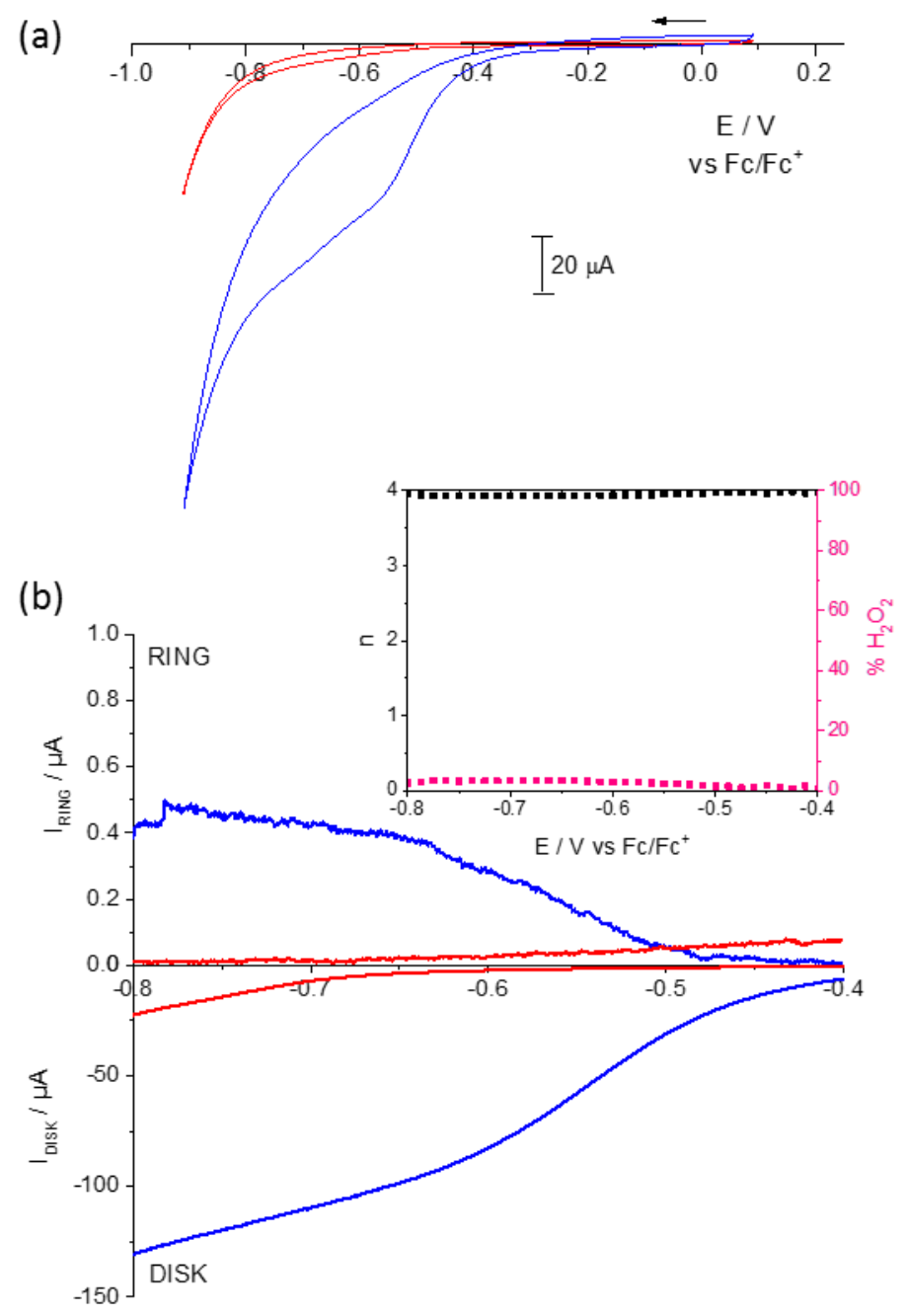

Figure 4. (a) Cyclic voltammograms (CV) on GC disk and (b) rotating ring-disk electrode

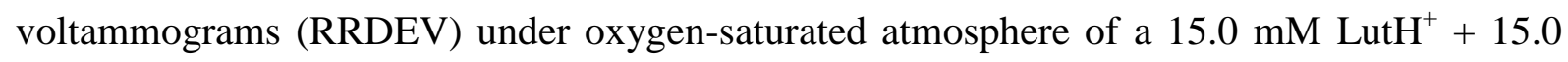
$\mathrm{mM}$ Lut solution in the absence (red lines) or presence (blue lines) of $0.1 \mathrm{mM}$ (dimer) $\mathbf{F e}^{\mathbf{o x}}$. MeCN 0.1 $\mathrm{M} \mathrm{Bu}_{4} \mathrm{NClO}_{4}, \mathrm{GC}(\varnothing=5 \mathrm{~mm})$; scan rates: $100 \mathrm{mV} \cdot \mathrm{s}^{-1}(\mathrm{CV}), 5 \mathrm{mV} \cdot \mathrm{s}^{-1}$ (RRDEV, the response does not change within the range $2-10 \mathrm{mV}^{-1}$ ); for RRDEV: rotation rate 1500 $\mathrm{rpm}$; ring current recorded with the Pt ring held at $0.2 \mathrm{~V} \mathrm{vs} \mathrm{Fc}^{+} / \mathrm{Fc}$ (for the blue curves, $i_{\text {ring }} 0.2 \mathrm{~V}$ has been corrected by subtracting $i_{\text {ring }} 0 \mathrm{~V}$, see Figure S16). The inset of (b) displays the RRDEV-determined $\%$ of produced $\mathrm{H}_{2} \mathrm{O}_{2}$ and the number of electrons $(n)$ consumed for reduction of one molecule of $\mathrm{O}_{2} v s$ applied potential. 
Rotating ring-disk electrode voltammetry (RRDEV) experiments were carried out for estimating $\mathrm{H}_{2} \mathrm{O}_{2} / \mathrm{H}_{2} \mathrm{O}$ selectivity and quantifying the production of $\mathrm{H}_{2} \mathrm{O}_{2}$ under electrochemical conditions (Figures 4b, S14-S15). The potential at the GC disk was scanned through the catalytic region (from $-0.4 \mathrm{~V}$ to $-0.8 \mathrm{~V} v s \mathrm{Fc}^{+} / \mathrm{Fc}$ ), and the potential at the $\mathrm{Pt}$ ring ( $E_{\text {ring }}$ ) was fixed at 0.2 (Figure $4 \mathrm{~b}$ ) or $0.43 \mathrm{~V}$ (Figure S15) $v s \mathrm{Fc}^{+} / \mathrm{Fc}^{58}$ in order to detect the oxidation of the ORR-generated hydrogen peroxide.

Under argon atmosphere, the ring current observed in the presence of $\mathbf{F e}^{\mathbf{o x}}$ and $\mathrm{LutH}^{+} / \mathrm{Lut}$ is mainly attributed to the re-oxidation of $\left[\mathbf{F e}_{2}{ }^{{ }^{S H}}\right]^{+}$formed on the disk, to regenerate $\mathbf{F e}^{\mathbf{o x}}$ (Figure S14). The ring current at $0.2 \mathrm{~V} v s \mathrm{Fc} / \mathrm{Fc}^{+}$(blue trace in Figure 4b) in the presence of $\mathbf{F e}^{\mathbf{o x}}$ and $\mathrm{LutH}^{+} /$Lut under dioxygen atmosphere can be thus attributed to the oxidation of $\mathrm{H}_{2} \mathrm{O}_{2}$ generated in the catalytic ORR process. Under these conditions, the Faradaic efficiency for $\mathrm{H}_{2} \mathrm{O}_{2}$ production is $\leq 3.5 \%$ in the explored potential window, corresponding to $\gtrsim 3.9$ electrons $(n)$ exchanged during the ORR process (see inset of Figure $4 \mathrm{~b}$ ). Similar results have been found at $E_{\text {ring }}=0.43 \mathrm{~V} v s \mathrm{Fc} / \mathrm{Fc}^{+}: \leq 12.5 \% \mathrm{H}_{2} \mathrm{O}_{2}, n \gtrsim 3.7$ (Figure S15). These studies, therefore, give evidence that the $\mathbf{F e}^{\mathbf{o x}}$ catalyst is selective for water production, and thus catalyzes almost exclusively $4 \mathrm{H}^{+} / 4 \mathrm{e}^{-}$ORR under electrochemical conditions.

\section{Mechanistic investigations of the $\mathrm{O}_{2}$ reduction process}

In support of the experimental observations, a series of density functional theory (DFT) calculations were performed to gain insight into the mechanistic details for catalytic reduction of dioxygen by $\left[\mathbf{F e}_{2}{ }^{\mathbf{S H}}\right]^{+}$(or $\mathbf{F e}^{\mathbf{o x}}$ ). We calculated individual structures along the proposed reaction cycle of Scheme 2 (using two different models that give comparable results, see Supporting Information, including Figures S17 - S22) and investigated reaction (free) energies of dioxygen binding and activation.

The catalytic process is initiated by the reduction of $\mathbf{F e}^{\mathbf{o x}}$ into $\left[\mathrm{Fe}_{2}{ }^{\mathbf{S H}}\right]^{+}$, the complex that does interact with $\mathrm{O}_{2}$. The DFT-optimized structure of $\left[\mathbf{F e}_{2}{ }^{{ }^{3 H}}\right]^{+}$fully matches the X-ray structure, and the high spin state of the $\mathrm{Fe}^{\mathrm{II}}$ ions is well predicted. Specifically, the calculated distances of Fe1-S1 and Fe2-S4 of 2.39 and $2.61 \AA$ match the crystal structure bond lengths excellently and indeed show elongation of the Fe-S bond for the thiol-ligated system. Note as well the predicted hydrogen bonding interaction between the terminally bound thiolate and the thiol $(\mathrm{S}-\mathrm{S}=3.582 \AA)$ in the optimized structure of $\left[\mathrm{Fe}_{2}{ }^{\mathbf{S H}}\right]^{+}$as observed experimentally. An almost thermoneutral dioxygen binding step with $\Delta G=5.6 \mathrm{kcal} \mathrm{mol}^{-1}\left(\triangle E+Z P E=-2.2 \mathrm{kcal} \mathrm{mol}^{-1}\right)$ leads to the formation of the trans-1,2- $\mu$-peroxo dinuclear $\mathrm{Fe}^{\mathrm{III}}$ complex, $\left[\mathrm{Fe}_{2}{ }^{\mathbf{O O} / \mathbf{S H}}\right]^{+}$(via a 
transient high-energy superoxo species, $\left[\mathrm{Fe}_{2}{ }^{\mathbf{O O} / \mathbf{S H}}\right]^{+}$, Figure S18 and Table S5). In contrast to the corresponding DFT-calculated structure of the dinuclear $\mathrm{Mn}^{\mathrm{III}}$-peroxo complex, ${ }^{30}$ the diiron complex $\left[\mathrm{Fe}_{2}{ }^{\mathbf{O O} / \mathrm{SH}^{+}}\right]^{+}$is much less symmetric with an almost linear $\mathrm{Fe}-\mathrm{O}-\mathrm{Fe}$ angle of $173^{\circ}$, while the second oxygen atom is coordinated to one iron only (Figure 5). As such, the structure of $\left[\mathrm{Fe}_{2}{ }^{\mathbf{O O} / \mathrm{SH}^{+}}\right]^{+}$resembles a side-on $\mathrm{Fe}^{\mathrm{III}}$-peroxo linked to a second mononuclear $\mathrm{Fe}^{\mathrm{III}}$ unit. Such $\mu-\eta^{1}: \eta^{2}$-peroxo coordination mode has been already observed in heme-peroxo copper models of the cytochrome $c$ oxidase. ${ }^{60-62}$

Attempts to optimize either a more symmetrical structure for the trans-1,2- $\mu$-peroxo diiron complex or a $c i s-\mu-1,2$-peroxo coordination mode failed and converged back to the geometry shown in Figure 5. The cis- $\mu$-1,2-peroxo mode is the exclusive coordination mode found in non-heme $\mathrm{Fe}^{\mathrm{III}}$ peroxo-bridged complexes, ${ }^{63-65}$ in which one or more additional bridges (e.g. carboxylate, phenolato) are often present to stabilize such species. Conversely, complexes with unsupported peroxo-bridged dimers as in $\mathrm{Fe}^{\mathrm{III}}$-tetraphenylporphyrins display a trans- $\mu$ 1,2 coordination mode as in the present case. ${ }^{66}$

We thus evaluated the capacity of the peroxo $\left[\mathbf{F e}_{2}{ }^{\mathbf{O O} / \mathbf{S H}}\right]^{+}$complex to evolve either via an internal proton transfer to form a hydroperoxo complex or via the breaking of the $\mathrm{O}-\mathrm{O}$ bond to generate a high-valent Fe-oxo species.

Concerning the intramolecular proton transfer pathway in $\left[\mathrm{Fe}_{2}{ }^{\mathbf{O O} / \mathbf{S H}^{+}}\right]^{+}$(Figure 5), a kinetic barrier of $12.8 \mathrm{kcal} \mathrm{mol}^{-1}$ has been calculated to generate the diiron(III)-hydroperoxo complex $\left[\mathrm{Fe}_{2}{ }^{\mathbf{O O H}}\right]^{+}$(Figure S22). Regarding the cleavage of the O-O bond, even if two different pathways were located (see SI for further details), the most favorable one corresponds to the generation of dinuclear $\mathrm{Fe}^{\mathrm{IV}}$ di-oxo intermediate $\left[\mathrm{Fe}_{2}(\boldsymbol{\mu}-\mathbf{O})_{2}{ }^{\mathrm{SH}}\right]^{+}$(Figure 5). However, the energy barrier of $15.9 \mathrm{kcal} \mathrm{mol}^{-1}$ for this reaction is larger than the barrier predicted to generate the protonated $\left[\mathrm{Fe}_{2}{ }^{\mathbf{O O H}}\right]^{+}$peroxo complex. These calculations are thus consistent with the fact that $\mathrm{H}_{2} \mathrm{O}_{2}$ can be selectively produced (in the presence of $\mathrm{Me}_{8} \mathrm{Fc}$ ), through the reaction of $\left[\mathrm{Fe}_{2}{ }^{\mathbf{O O H}}\right]^{+}$with an additional proton and the formation of $\mathbf{F e}_{\mathbf{2}}{ }^{\mathbf{o x}}$ (Scheme 2, pathway B). 


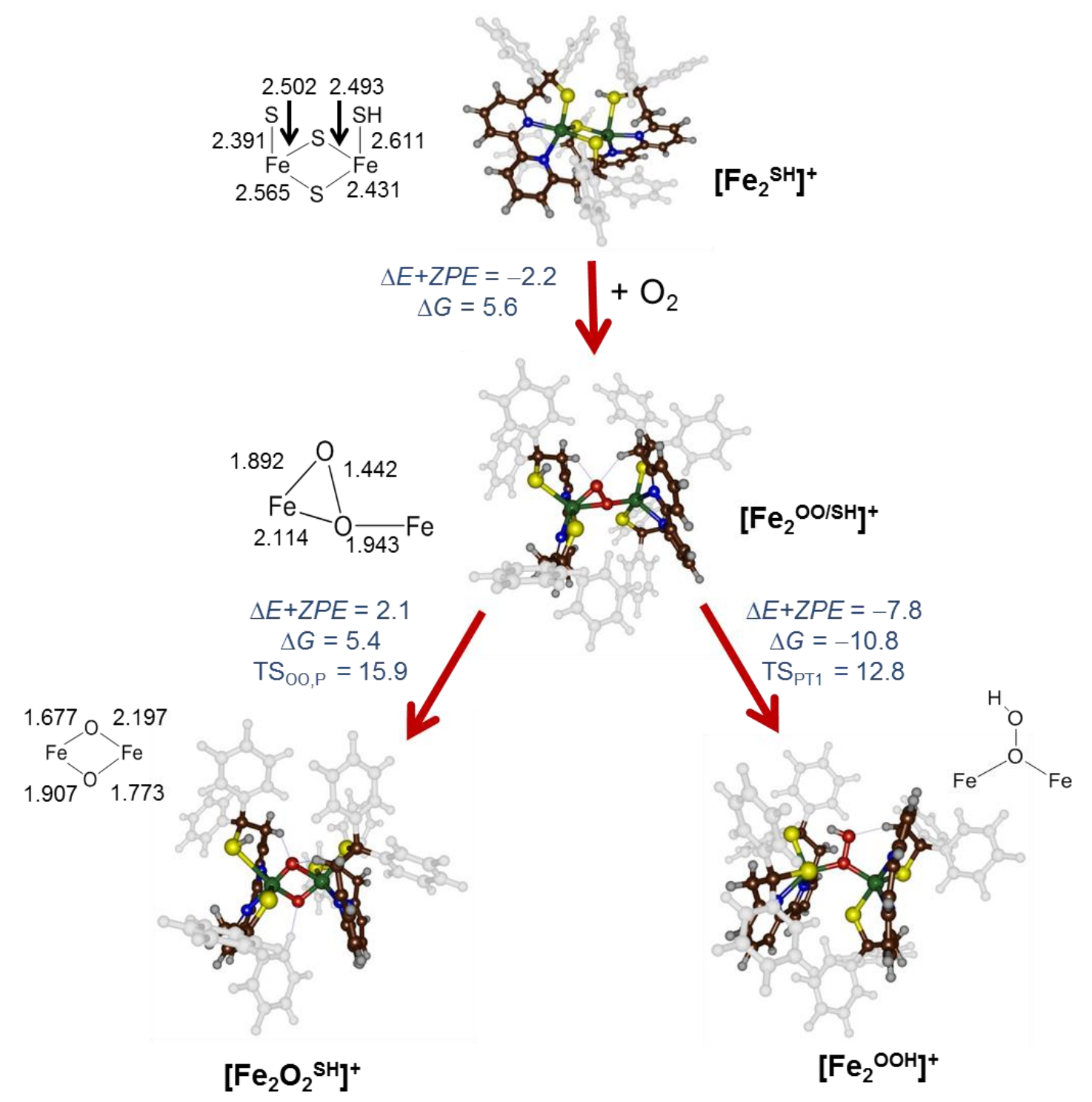

Figure 5. Optimized geometries of $\left[\mathrm{Fe}_{2}{ }^{\mathrm{SH}}\right]^{+},\left[\mathrm{Fe}_{2}{ }^{\mathrm{OO} / \mathrm{SH}}\right]^{+},\left[\mathrm{Fe}_{2}(\mu-\mathrm{O})_{2}{ }^{\mathrm{SH}}\right]^{+}$and $\left[\mathrm{Fe}_{2}{ }^{\mathrm{OOH}}\right]^{+}$in the antiferromagnetically coupled singlet spin state with bond lengths in angstroms. For the sake of simplicity, the peroxo intermediate is considered only in its protonated form. Reaction energies $(\triangle E+Z P E)$ and reaction free energies $(\Delta G)$ at $298 \mathrm{~K}$ are given in kcal mol ${ }^{-1}$ for the large model structures. Transition state energies (in $\mathrm{kcal} \mathrm{mol}^{-1}$ ) are reported at UB3LYP/BS1//UB3LYP/BS2 and contain zero-point and solvent corrections.

When electrons are delivered electrochemically, catalysis mainly occurs through a $4 \mathrm{H}^{+} / 4 \mathrm{e}^{-}$ ORR mechanism. In this case we propose that $\mathrm{O}_{2}$ activation involves the formation of either $\left[\mathrm{Fe}_{2}{ }^{\mathrm{OO} / \mathrm{SH}}\right]^{+}$(or $\left[\mathrm{Fe}_{2}{ }^{\mathrm{OOH}}\right]^{+}$), which is then immediately reduced at the electrode before it can react with an additional proton. Indeed in Scheme 2, pathway A requires the use of three protons and two electrons to convert $\left[\mathrm{Fe}_{2}{ }^{\mathbf{O O} / \mathrm{SH}}\right]^{+}$into $\mathbf{F e}^{\mathbf{o x}}$ with production of water. The full prediction of this complicated mechanism involving four protons and four electrons in 
sequential and/or coupled manner to produce $\mathrm{H}_{2} \mathrm{O}$ through an $\mathrm{O}-\mathrm{O}$ bond cleavage is out of the scope of the present study.

Pathways $\mathbf{A}$ and $\mathbf{B}$ are both exergonic, even if route $\mathbf{B}$ has a much lower driving force $\left(\Delta G^{\mathbf{B}}=\right.$ $-9.2 \mathrm{kcal} \mathrm{mol}^{-1}$ vs $\Delta G^{\mathbf{A}}=-39.2 \mathrm{kcal} \mathrm{mol}^{-1}$ ). The fact that $\left[\mathbf{F e}_{\mathbf{2}}{ }^{\mathbf{S H}}\right]^{+}$has a proton located in the metal coordination sphere means that during the catalytic cycle there is competition between dioxygen bond cleavage and proton transfer, whereby a possible pathway to $\mathrm{H}_{2} \mathrm{O}_{2}$ formation becomes possible.
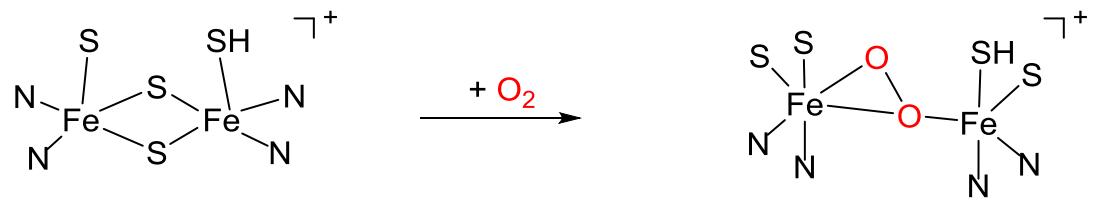

$\left[\mathrm{Fe}_{2} \mathrm{SH}^{+}\right.$

$\left[\mathrm{Fe}_{2}{ }^{\mathrm{OO} / \mathrm{SH}^{+}}\right]^{+}$
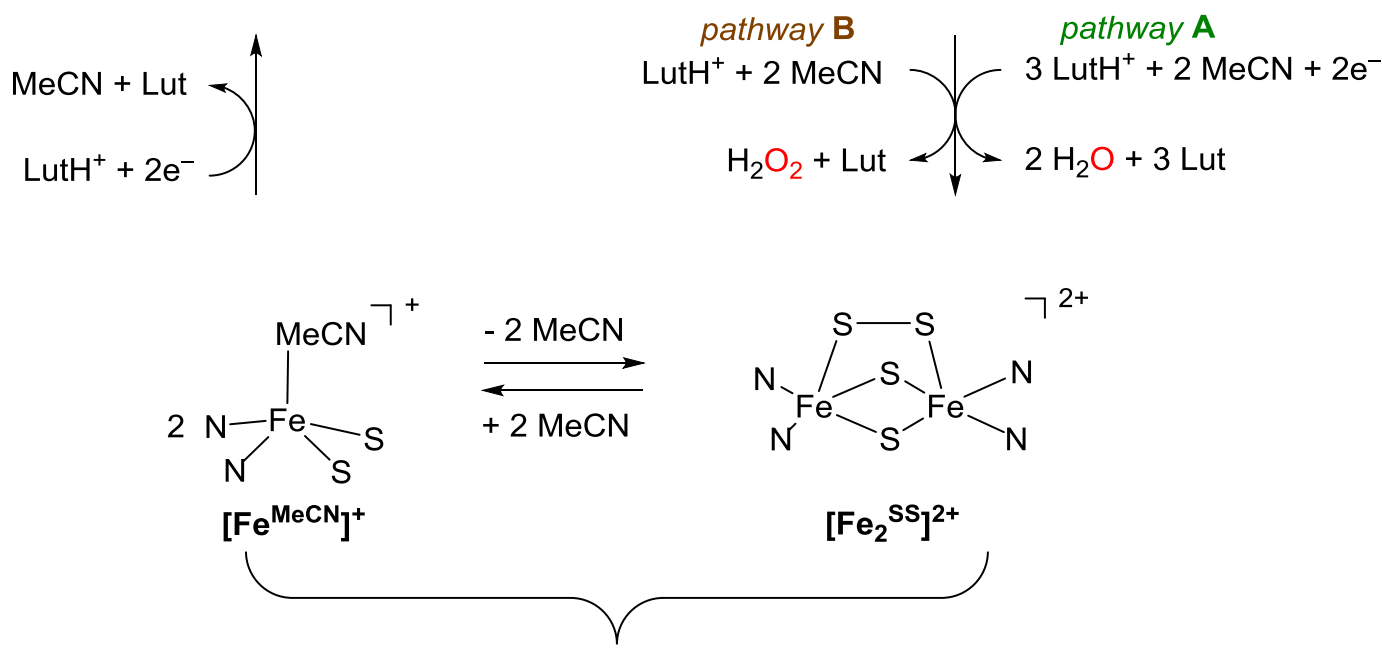

$$
\mathrm{Fe}^{\mathrm{ox}}
$$

Scheme 2. Proposed $4 \mathrm{H}^{+} / 4 \mathrm{e}^{-}$(electrochemically driven) vs $2 \mathrm{H}^{+} / 2 \mathrm{e}^{-}$(chemical reducing agent) ORR catalysis by $\left[\mathrm{Fe}_{2}{ }^{\mathbf{S H}}\right]^{+}$(or $\mathbf{F e}^{\mathbf{o x}}$ ). For the sake of simplicity, only the peroxo $\left[\mathrm{Fe}_{\mathbf{2}}{ }^{\mathbf{O O} / \mathbf{S H}}\right]^{+}$ intermediate is depicted (and not the hydroperoxo $\left[\mathrm{Fe}_{2}{ }^{\mathbf{O O H}}\right]^{+}$species).

\section{Discussion and Conclusion}

In this study, we report the reactivity of a unique dinuclear iron-thiolate complex, $\left[\mathbf{F e}_{2}{ }^{\mathbf{S H}^{+}}\right]^{+}$ (and of its oxidized form, $\mathbf{F e}^{\mathbf{0 x}}$ ), as an efficient ORR (electro)catalyst. Thiolate ligation has been previously proposed to promote the activation of molecular oxygen, ${ }^{67}$ via (i) stabilization of metal-peroxo intermediates, ${ }^{68-73}$ (ii) decrease of the activation barrier for $\mathrm{O}_{2}$ binding, ${ }^{53,74}$ (iii) decrease of the metal redox potential, ${ }^{75}$ (iv) increase of the basicity of bound substrates ${ }^{76}$ or (v) labilization of the trans sites. ${ }^{75}$ Our study confirms and further generalizes 
this aptitude: the thiolate-rich N2S2-donor $\mathrm{LS}^{2-}$ ligand, in the presence of $\mathrm{Fe}^{\mathrm{II}}$ (this study) or $\mathrm{Mn}^{\mathrm{II}}$ (previously reported work) ${ }^{32,45}$ promotes $\mathrm{O}_{2}$ activation at the coordinated transition metal ion. Although the continuous regeneration of the initial complex $\left[\mathrm{Fe}_{2}{ }^{\mathrm{SH}}\right]^{+}$during catalytic turnover entails that sulfur-oxygenation is limited in the present system during the ORR catalysis, this is not the case for other mononuclear Fe-thiolate complexes mainly reported by the Limberg and Goldberg groups. ${ }^{77-81}$ Clearly, the thiolate groups of the $\mathrm{LS}^{2-}$ ligand system are much more difficult to oxidize than the cysteinate group used in the Limberg and Goldberg systems. Indeed, our calculations indicate little or no spin density on the thiolate groups.

A peculiar feature of these $\left[\mathbf{M}_{2}{ }^{\mathbf{S H}}\right]^{+}$catalysts $(\mathrm{M}=\mathrm{Fe}, \mathrm{Mn})$ is the presence of one thiol group coordinated to the metal centers that can act as a proton relay during catalysis. This is a unique example of a sulfur-based pendant acid in ORR catalysis, because most of them are Oand/or N-based (carboxylic acids, ammonium, urea, etc.). ${ }^{1,82,83}$ The nature of the proton relay can still play a role as potential tunable agent of the selectivity; however no general trend can be drawn up now. Interestingly, while Kojima et al observed an enhancement for $4 \mathrm{H}^{+} / 4 \mathrm{e}^{-}$ ORR catalysis in the presence of pendant pyridine close to a $\mathrm{Cu}$ site, ${ }^{28}$ Machan et al. described a Schiff-based Mn catalyst with a pendant phenol that displays selective $2 \mathrm{H}^{+} / 2 \mathrm{e}^{-}$ ORR activity. ${ }^{33}$

The investigation of isostructural iron- and manganese-based catalysts evidences that even if both display similar selectivity in the presence of a chemical reducing agent under similar experimental conditions, $\left[\mathbf{F e}_{\mathbf{2}}{ }^{\mathbf{S H}}\right]^{+}$is $\sim 6$ times more reactive than $\left[\mathbf{M n}_{\mathbf{2}}{ }^{\mathbf{S H}}\right]^{+}$, (on the basis of the $\mathrm{TOF}_{\mathrm{i}}$ values determined in the presence of $\mathrm{Me}_{8} \mathrm{Fc}$ ). This difference in efficiency can be related to the reduction potential of the catalysts, $\left[\mathrm{Fe}_{2}{ }^{\mathrm{SH}^{+}}\right]^{+}$being more easily oxidized than $\left[\mathbf{M n}_{2}{ }^{\mathrm{SH}}\right]^{+}$(see above).

The most attractive properties of $\left[\mathrm{Fe}_{2}{ }^{\mathbf{S H}}\right]^{+}$as an ORR catalyst are that: (i) this is the first homogeneous ORR catalyst based on non-heme iron and (ii) its selectivity can be tuned as a function on the mode of electron delivery (chemical vs electrochemical catalysis).

Although iron porphyrin systems have been largely investigated, ${ }^{1,13-15,84}$ this is not the case for non-heme iron complexes. To our knowledge, only one family of Fe complexes supported by non-heme ligands has been previously reported in the ORR domain. ${ }^{85}$ However, the described tetrapyridyl mononuclear complexes only react with $\mathrm{O}_{2}$ stoichiometrically, and not catalytically (the initial complex can be regenerated only in a two-step process). We believe that the discovery of such non-heme iron catalyst for ORR catalysis will pave the way to new structure-reactivity correlation studies encompassing both heme and non-heme compounds. 
As hydrogen peroxide is generated in both cases (predominantly and up to $95 \%$ or in less than $\sim 10 \%$ in chemical and electrochemical catalysis, respectively), it can be proposed that a common intermediate, that is, the calculated iron-peroxo complex $\left[\mathrm{Fe}_{2}{ }^{\mathbf{O O} / \mathbf{S H}^{+}}\right]^{+}$, is generated during catalysis (Scheme 2). The reactivity of such a peroxo intermediate has been proposed to be central for rationalizing the selectivity of homogeneous ORR catalysts. A study on a series of $\mathrm{Cu}^{\text {II }}$ catalysts with tri- and tetrapodal nitrogen-donor ligands has evidenced that the electronic and structural properties of the generated peroxo intermediates are critical for tuning the selectivity of the ORR process. ${ }^{23}$

The tunable selectivity of the $\left[\mathbf{F e}_{\mathbf{2}}{ }^{\mathbf{S H}}\right]^{+}$catalyst as a function of the electron delivering manner implies that the peroxo $\left[\mathrm{Fe}_{2}{ }^{\mathbf{O O} / \mathbf{S H}}\right]^{+}\left(\right.$or $\left[\mathrm{Fe}_{2}{ }^{\mathbf{O O H}}\right]^{+}$) intermediate can either (i) react with one proton to produce $\mathrm{H}_{2} \mathrm{O}_{2}$ (with $\mathrm{Me}_{8} \mathrm{Fc}$ as reducing agent), or (ii) be reduced to generate $\mathrm{H}_{2} \mathrm{O}$ as the main product after successive reduction and protonation steps (under electro-assisted catalysis). These two pathways are supported by DFT calculations, which predict that both are thermodynamically feasible. The production of $\mathrm{H}_{2} \mathrm{O}_{2}$ is further supported by the fact that the formation of the hydroperoxo intermediate is thermodynamically and kinetically favored over the generation of high valent $\mathrm{Fe}^{\mathrm{IV}}$ di-oxo species arising from "direct" $\mathrm{O}-\mathrm{O}$ bond rupture (see Figure 5). Concerning $\mathrm{H}_{2} \mathrm{O}$ production, the $\mathrm{O}-\mathrm{O}$ bond cleavage should thus occur after further reduction of the (hydro)peroxo complex. The tuning of the selectivity can be interpreted in terms of a competition between acid-base and redox processes with the $\left[\mathrm{Fe}_{\mathbf{2}}{ }^{\mathbf{O O} / \mathbf{S H}}\right]^{+}$(or $\left[\mathrm{Fe}_{2}{ }^{\mathbf{O O H}}\right]^{+}$) peroxo as the key intermediate. Indeed, when the concentration of the chemical reductant is increased less $\mathrm{H}_{2} \mathrm{O}_{2}$ is generated (see Table S3), suggesting that the peroxo intermediate needs to be in a more reducing environment to be reduced (and then to break the $\mathrm{O}-\mathrm{O}$ bond to generate $\mathrm{H}_{2} \mathrm{O}$ ) before it gets protonated (to generate $\mathrm{H}_{2} \mathrm{O}_{2}$ ). When electrochemically driven, the electron transfer kinetics for its reduction is likely faster because it occurs in the reaction-diffusion layer at the immediate vicinity of the electrode, compared to bulk solution.

The present study thus represents a substantial contribution towards the understanding of the factors controlling catalytic efficiency and selectivity of homogeneous ORR catalysis, in terms of ligand design, nature of transition metal(s), proton and electron delivery.

\section{Acknowledgements}

The authors gratefully acknowledge research support of this work by the Labex arcane (ANR11-LABX-003), the Agence National de la Recherche and the Deutsche Forschungsgemeinschaft (grants no. ANR-16-CE92_0012_01 and DFG Me1313/14-1, 
NiFeMim), the COST Action CM1305 (EcostBio) especially via the STSM 34962 and the financial support of China Scholarship Council (L.W.). FGCR thanks the Conacyt Mexico for a studentship.

\section{Table of Contents}

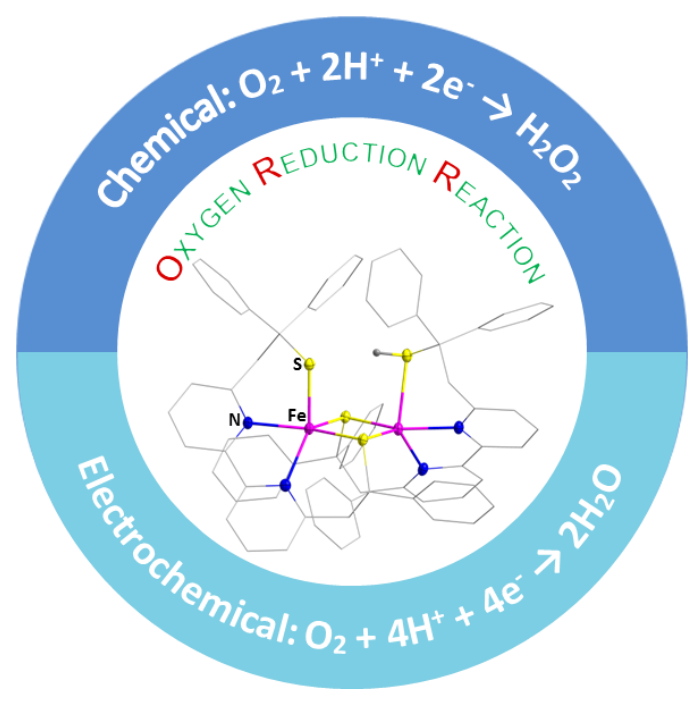

\section{References}

(1) Pegis, M. L.; Wise, C. F.; Martin, D. J.; Mayer, J. M. Oxygen Reduction by Homogeneous Molecular Catalysts and Electrocatalysts. Chem. Rev. 2018, 118, 2340.

(2) Gewirth, A. A.; Varnell, J. A.; DiAscro, A. M. Nonprecious Metal Catalysts for Oxygen Reduction in Heterogeneous Aqueous Systems. Chem. Rev. 2018, 118, 2313.

(3) Adler, S. B. Factors Governing Oxygen Reduction in Solid Oxide Fuel Cell Cathodes. Chem. Rev. 2004, 104, 4791.

(4) Gao, Z.; Mogni, L. V.; Miller, E. C.; Railsback, J. G.; Barnett, S. A. A perspective on low-temperature solid oxide fuel cells. Energy Environ. Sci. 2016, 9, 1602.

(5) Shao, M.; Chang, Q.; Dodelet, J.-P.; Chenitz, R. Recent Advances in Electrocatalysts for Oxygen Reduction Reaction. Chem. Rev. 2016, 116, 3594.

(6) Campos-Martin, J. M.; Blanco-Brieva, G.; Fierro, J. L. G. Hydrogen peroxide synthesis: an outlook beyond the anthraquinone process. Angew. Chem., Int. Ed. 2006, 45,6962 .

(7) Yamada, Y.; Yoneda, M.; Fukuzumi, S. High and robust performance of H2O2 fuel cells in the presence of scandium ion. Energy Environ. Sci. 2015, 8, 1698.

(8) Yamada, Y.; Fukunishi, Y.; Yamazaki, S.-i.; Fukuzumi, S. Hydrogen peroxide as sustainable fuel: electrocatalysts for production with a solar cell and decomposition with a fuel cell. Chem. Commun. 2010, 46, 7334.

(9) Chatterjee, S.; Sengupta, K.; Mondal, B.; Dey, S.; Dey, A. Factors Determining the Rate and Selectivity of $4 \mathrm{e}-/ 4 \mathrm{H}+$ Electrocatalytic Reduction of Dioxygen by Iron Porphyrin Complexes. Acc. Chem. Res. 2017, 50, 1744.

(10) Mukherjee, S.; Mukherjee, A.; Bhagi-Damodaran, A.; Mukherjee, M.; Lu, Y.; Dey, A. A biosynthetic model of cytochrome c oxidase as an electrocatalyst for oxygen reduction. Nature Communications 2015, 6, 8467. 
(11) Artero, V. Bioinspired catalytic materials for energy-relevant conversions. Nature Energy 2017, 2, 17131.

(12) Jaouen, F.; Jones, D.; Coutard, N.; Artero, V.; Strasser, P.; Kucernak, A. Toward Platinum Group Metal-Free Catalysts for Hydrogen/Air Proton-Exchange Membrane Fuel Cells. Johnson Matthey Technology Review 2018, 62, 231.

(13) Fukuzumi, S.; Lee, Y.-M.; Nam, W. Mechanisms of Two-Electron versus Four-Electron Reduction of Dioxygen Catalyzed by Earth-Abundant Metal Complexes. ChemCatChem 2018, 10, 9.

(14) Zhang, W.; Lai, W.; Cao, R. Energy-Related Small Molecule Activation Reactions: Oxygen Reduction and Hydrogen and Oxygen Evolution Reactions Catalyzed by Porphyrin- and Corrole-Based Systems. Chem. Rev. 2017, 117, 3717.

(15) Collman, J. P.; Boulatov, R.; Sunderland, C. J.; Fu, L. Functional Analogues of Cytochrome c Oxidase, Myoglobin, and Hemoglobin. Chem. Rev. 2004, 104, 561.

(16) Dogutan, D. K.; Stoian, S. A.; McGuire, R.; Schwalbe, M.; Teets, T. S.; Nocera, D. G. Hangman corroles: efficient synthesis and oxygen reaction chemistry. J. Am. Chem. Soc. 2011, 133, 131.

(17) Rosenthal, J.; Nocera, D. G. Role of Proton-Coupled Electron Transfer in 0O Bond Activation. Acc. Chem. Res. 2007, 40, 543.

(18) Yeh, C.-Y.; Chang, C. J.; Nocera, D. G. "Hangman" Porphyrins for the Assembly of a Model Heme Water Channel. J. Am. Chem. Soc. 2001, 123, 1513.

(19) Fukuzumi, S.; Mochizuki, S.; Tanaka, T. Efficient reduction of dioxygen with ferrocene derivatives, catalyzed by metalloporphyrins in the presence of perchloric acid. Inorg. Chem. 1989, 28, 2459.

(20) Fukuzumi, S.; Okamoto, K.; Gros, C. P.; Guilard, R. Mechanism of FourElectron Reduction of Dioxygen to Water by Ferrocene Derivatives in the Presence of Perchloric Acid in Benzonitrile, Catalyzed by Cofacial Dicobalt Porphyrins. J. Am. Chem. Soc. 2004, 126, 10441.

(21) Honda, T.; Kojima, T.; Fukuzumi, S. Proton-Coupled Electron-Transfer Reduction of Dioxygen Catalyzed by a Saddle-Distorted Cobalt Phthalocyanine. J. Am. Chem. Soc. 2012, 134, 4196.

(22) Wang, Y.-H.; Pegis, M. L.; Mayer, J. M.; Stahl, S. S. Molecular Cobalt Catalysts for 02 Reduction: Low-Overpotential Production of H2O2 and Comparison with IronBased Catalysts. J. Am. Chem. Soc. 2017, 139, 16458.

(23) Kakuda, S.; Peterson, R. L.; Ohkubo, K.; Karlin, K. D.; Fukuzumi, S. Enhanced Catalytic Four-Electron Dioxygen (02) and Two-Electron Hydrogen Peroxide (H2O2) Reduction with a Copper(II) Complex Possessing a Pendant Ligand Pivalamido Group. J. Am. Chem. Soc. 2013, 135, 6513.

(24) Tahsini, L.; Kotani, H.; Lee, Y.-M.; Cho, J.; Nam, W.; Karlin, K. D.; Fukuzumi, S. Electron-Transfer Reduction of Dinuclear Copper Peroxo and Bis- $\mu$-oxo Complexes Leading to the Catalytic Four-Electron Reduction of Dioxygen to Water. Chem. Eur. J. 2012, 18, 1084.

(25) Fukuzumi, S.; Tahsini, L.; Lee, Y.-M.; Ohkubo, K.; Nam, W.; Karlin, K. D. Factors That Control Catalytic Two- versus Four-Electron Reduction of Dioxygen by Copper Complexes. J. Am. Chem. Soc. 2012, 134, 7025.

(26) Fukuzumi, S.; Kotani, H.; Lucas, H. R.; Doi, K.; Suenobu, T.; Peterson, R. L.; Karlin, K. D. Mononuclear Copper Complex-Catalyzed Four-Electron Reduction of Oxygen. J. Am. Chem. Soc. 2010, 132, 6874. 
(27) Fukuzumi, S.; Karlin, K. D. Kinetics and thermodynamics of formation and electron-transfer reactions of $\mathrm{Cu}-\mathrm{O} 2$ and $\mathrm{Cu} 2-\mathrm{O} 2$ complexes. Coord. Chem. Rev. 2013, 257, 187.

(28) Kotani, H.; Yagi, T.; Ishizuka, T.; Kojima, T. Enhancement of 4-electron 02 reduction by a $\mathrm{Cu}(\mathrm{II})$-pyridylamine complex via protonation of a pendant pyridine in the second coordination sphere in water. Chem. Commun. 2015, 51, 13385.

(29) Adam, S. M.; Garcia-Bosch, I.; Schaefer, A. W.; Sharma, S. K.; Siegler, M. A.; Solomon, E. I.; Karlin, K. D. Critical Aspects of Heme-Peroxo-Cu Complex Structure and Nature of Proton Source Dictate Metal-Operoxo Breakage versus Reductive 0-O Cleavage Chemistry. J. Am. Chem. Soc. 2017, 139, 472.

(30) Schaefer, A. W.; Kieber-Emmons, M. T.; Adam, S. M.; Karlin, K. D.; Solomon, E. I. Phenol-induced 0-O bond cleavage in a low-spin heme-peroxo-copper complex: Implications for 02 reduction in heme-copper oxidases. J. Am. Chem. Soc. 2017, 139, 7958.

(31) Evans, D. F.; Sheriff, T. S. The production of hydrogen peroxide from dioxygen and hydroxylamine catalyzed by manganese complexes. J. Chem. Soc., Chem. Commun. 1985, 1407.

(32) Gennari, M.; Brazzolotto, D.; Pecaut, J.; Cherrier, M. V.; Pollock, C. J.; DeBeer, S.; Retegan, M.; Pantazis, D. A.; Neese, F.; Rouzieres, M.; Clerac, R.; Duboc, C. Dioxygen Activation and Catalytic Reduction to Hydrogen Peroxide by a Thiolate-Bridged Dimanganese(II) Complex with a Pendant Thiol. J. Am. Chem. Soc. 2015, 137, 8644.

(33) Hooe, S. L.; Rheingold, A. L.; Machan, C. W. Electrocatalytic Reduction of Dioxygen to Hydrogen Peroxide by a Molecular Manganese Complex with a BipyridineContaining Schiff Base Ligand. J. Am. Chem. Soc. 2018, 140, 3232.

(34) Shook, R. L.; Peterson, S. M.; Greaves, J.; Moore, C.; Rheingold, A. L.; Borovik, A. S. Catalytic Reduction of Dioxygen to Water with a Monomeric Manganese Complex at Room Temperature. J. Am. Chem. Soc. 2011, 133, 5810.

(35) Wasylenko, D. J.; Rodríguez, C.; Pegis, M. L.; Mayer, J. M. Direct Comparison of Electrochemical and Spectrochemical Kinetics for Catalytic Oxygen Reduction. J. Am. Chem. Soc. 2014, 136, 12544.

(36) Asahi, M.; Yamazaki, S.-i.; Itoh, S.; Ioroi, T. Electrochemical reduction of dioxygen by copper complexes with pyridylalkylamine ligands dissolved in aqueous buffer solution: the relationship between activity and redox potential. Dalton Trans. 2014, 43, 10705.

(37) Kopf, M. A.; Varech, D.; Tuchagues, J. P.; Mansuy, D.; Artaud, I. New intermediate-spin chloroiron(III) complex with a mixed nitrogen-sulfur co-ordination. $J$. Chem. Soc., Dalton Trans. 1998, 991.

(38) Costas, M.; Mehn, M. P.; Jensen, M. P.; Que, L., Jr. Dioxygen Activation at Mononuclear Nonheme Iron Active Sites: Enzymes, Models, and Intermediates. Chem. Rev. 2004, 104, 939.

(39) Gamba, I.; Codola, Z.; Lloret-Fillol, J.; Costas, M. Making and breaking of the 0-0 bond at iron complexes. Coord. Chem. Rev. 2017, 334, 2.

(40) Hong, S.; Lee, Y.-M.; Ray, K.; Nam, W. Dioxygen activation chemistry by synthetic mononuclear nonheme iron, copper and chromium complexes. Coord. Chem. Rev. 2017, 334, 25.

(41) Ray, K.; Pfaff, F. F.; Wang, B.; Nam, W. Status of reactive non-heme metaloxygen intermediates in chemical and enzymatic reactions. J. Am. Chem. Soc. 2014, 136, 13942. 
(42) Segaud, N.; Anxolabehere-Mallart, E.; Senechal-David, K.; Acosta-Rueda, L.; Robert, M.; Banse, F. Electrochemical study of a nonheme Fe(II) complex in the presence of dioxygen. Insights into the reductive activation of 02 at $\mathrm{Fe}(\mathrm{II})$ centers. Chem. Sci. 2015, 6, 639 .

(43) Thibon, A.; England, J.; Martinho, M.; Young, V. G.; Frisch, J. R.; Guillot, R.; Girerd, J.-J.; Muenck, E.; Que, L., Jr.; Banse, F. Proton- and reductant-assisted dioxygen activation by a nonheme iron(II) complex to form an oxoiron(IV) intermediate. Angew. Chem., Int. Ed. 2008, 47, 7064.

(44) Cavazza, C.; Bochot, C.; Rousselot-Pailley, P.; Carpentier, P.; Cherrier, M. V.; Martin, L.; Marchi-Delapierre, C.; Fontecilla-Camps, J. C.; Menage, S. Crystallographic snapshots of the reaction of aromatic $\mathrm{C}-\mathrm{H}$ with $\mathrm{O} 2$ catalysed by a protein-bound iron complex. Nat. Chem. 2010, 2, 1069.

(45) Brazzolotto, D.; Cantú Reinhard, F. G.; Smith-Jones, J.; Retegan, M.; Amidani, L.; Faponle, A. S.; Ray, K.; Philouze, C.; de Visser, S. P.; Gennari, M.; Duboc, C. A High-Valent Non-Heme $\mu$-Oxo Manganese(IV) Dimer Generated from a Thiolate-Bound Manganese(II) Complex and Dioxygen. Angew. Chem. Int. Ed. 2017, 56, 8211.

(46) Addison, A. W.; Rao, T. N.; Reedijk, J.; Vanrijn, J.; Verschoor, G. C. Synthesis, structure, and spectroscopic properties of copper(II) compounds containing nitrogensulphur donor ligands; the crystal and molecular structure of aqua[1,7-bis(Nmethylbenzimidazol-2' -yl)-2,6-dithiaheptane]copper(II) perchlorate J. Chem. Soc., Dalton Trans. 1984, 1349.

(47) Conroy-Lewis, F. M.; Simpson, S. J. Molecular mercaptan (thiol) complexes: the synthesis of the tert-butanethiol complexes [Ru( $75-\mathrm{C} 5 \mathrm{H} 5)(\mathrm{PPh} 3)($ tert-BuNC)(tertBuSH)]PF6 and $[\mathrm{Ru}(\eta 5-\mathrm{C} 5 \mathrm{H} 5)(\mathrm{dppm})($ tert-BuSH)]PF6 and the x-ray single crystal structure of $\quad[\mathrm{Ru}(\eta 5-\mathrm{C} 5 \mathrm{H} 5)(\mathrm{dppm})($ tert-BuSH) $] \mathrm{PF} 6 \quad[\mathrm{dppm}=$ bis(diphenylphosphino)methane]. J. Chem. Soc., Chem. Commun. 1991, 388.

(48) McGuire, D. G.; Khan, M. A.; Ashby, M. T. Discontinuum between a Thiolate and a Thiol Ligand. Inorg. Chem. 2002, 41, 2202.

(49) Ma, E. S. F.; Rettig, S. J.; Patrick, B. O.; James, B. R. Ruthenium(II) Thiol and H2S Complexes: Synthesis, Characterization, and Thermodynamic Properties. Inorg. Chem. 2012, 51, 5427.

(50) Allan, C. B.; Davidson, G.; Choudhury, S. B.; Gu, Z.; Bose, K.; Day, R. O.; Maroney, M. J. Protonation and Alkylation of a Dinuclear Nickel Thiolate Complex. Inorg. Chem. 1998, 37, 4166.

(51) Wang, L.; Cantú Reinhard, F. G.; Philouze, C.; Demeshko, S.; de Visser, S. P.; Meyer, F.; Gennari, M.; Duboc, C. Solvent- and Halide-Induced (Inter)conversion between Iron(II)-Disulfide and Iron(III)-Thiolate Complexes. Chem. Eur. J. 2018, 24, 11973.

(52) Lianke, W.; G., C. R. F.; Christian, P.; Serhiy, D.; P., d. V. S.; Franc, M.; Marcello, G.; Carole, D. Solvent- and Halide-Induced (Inter)conversion between Iron(II)Disulfide and Iron(III)-Thiolate Complexes. Chem. Eur. J., 0.

(53) Kovacs, J. A.; Brines, L. M. Understanding how the thiolate sulfur contributes to the function of the non-heme iron enzyme superoxide reductase. Acc. Chem. Res. 2007, 40, 501.

(54) Takamura, K.; Matsubara, C.; Matsumoto, T. Reaction specificity of a titanium(IV)-porphyrin complex to hydrogen peroxide in view of an Ab initio study. Anal. Sci. 2008, 24, 401.

(55) Matsubara, C.; Kawamoto, N.; Takamura, K. Oxo[5, 10, 15, 20-tetra(4pyridyl)porphyrinato]titanium(IV): an ultra-high sensitivity spectrophotometric reagent for hydrogen peroxide. Analyst 1992, 117, 1781. 
(56) Rodima, T.; Kaljurand, I.; Pihl, A.; Maeemets, V.; Leito, I.; Koppel, I. A. AcidBase Equilibria in Nonpolar Media. 2. Self-Consistent Basicity Scale in THF Solution Ranging from 2-Methoxypyridine to EtP1(pyrr) Phosphazene. J. Org. Chem. 2002, 67, 1873.

(57) Huan, T. N.; Simon, P.; Rousse, G.; Genois, I.; Artero, V.; Fontecave, M. Porous dendritic copper: an electrocatalyst for highly selective $\mathrm{CO} 2$ reduction to formate in water/ionic liquid electrolyte. Chem. Sci. 2017, 8, 742.

(58) Passard, G.; Ullman, A. M.; Brodsky, C. N.; Nocera, D. G. Oxygen Reduction Catalysis at a Dicobalt Center: The Relationship of Faradaic Efficiency to Overpotential. J. Am. Chem. Soc. 2016, 138, 2925.

(59) Gerken, J. B.; Stahl, S. S. High-Potential Electrocatalytic 02 Reduction with Nitroxyl/NOx Mediators: Implications for Fuel Cells and Aerobic Oxidation Catalysis. ACS Cent. Sci. 2015, 1, 234.

(60) Chishiro, T.; Shimazaki, Y.; Tani, F.; Tachi, Y.; Naruta, Y.; Karasawa, S.; Hayami, S.; Maeda, Y. Isolation and crystal structure of a peroxo-bridged heme-copper complex. Angew. Chem.-Int. Edit. 2003, 42, 2788.

(61) Hematian, S.; Garcia-Bosch, I.; Karlin, K. D. Synthetic Heme/Copper Assemblies: Toward an Understanding of Cytochrome c Oxidase Interactions with Dioxygen and Nitrogen Oxides. Acc. Chem. Res. 2015, 48, 2462.

(62) Quist, D. A.; Diaz, D. E.; Liu, J. J.; Karlin, K. D. Activation of dioxygen by copper metalloproteins and insights from model complexes. JBIC Journal of Biological Inorganic Chemistry 2017, 22, 253.

(63) Zhang, X.; Furutachi, H.; Fujinami, S.; Nagatomo, S.; Maeda, Y.; Watanabe, Y.; Kitagawa, T.; Suzuki, M. Structural and Spectroscopic Characterization of $(\mu$-Hydroxo or $\mu$-Oxo)( $\mu$-peroxo)diiron(III) Complexes: Models for Peroxo Intermediates of NonHeme Diiron Proteins. J. Am. Chem. Soc. 2005, 127, 826.

(64) Yanhong, D.; Shiping, Y.; G., Y. V.; Lawrence, Q. Crystal Structure Analysis of a Synthetic Non-Heme Diiron?02 Adduct: Insight into the Mechanism of Oxygen Activation. Angewandte Chemie International Edition in English 1996, 35, 618.

(65) Ookubo, T.; Sugimoto, H.; Nagayama, T.; Masuda, H.; Sato, T.; Tanaka, K.; Maeda, Y.; Ōkawa, H.; Hayashi, Y.; Uehara, A.; Suzuki, M. cis- $\mu-1,2-P e r o x o$ Diiron Complex: Structure and Reversible Oxygenation. J. Am. Chem. Soc. 1996, 118, 701.

(66) Chin, D.-H.; La Mar, G. N.; Balch, A. L. Mechanism of autoxidation of iron(II) porphyrins. Detection of a peroxo-bridged iron(III) porphyrin dimer and the mechanism of its thermal decomposition to the oxo-bridged iron(III) porphyrin dimer. J. Am. Chem. Soc. 1980, 102, 4344.

(67) Brines, L. M.; Shearer, J.; Fender, J. K.; Schweitzer, D.; Shoner, S. C.; Barnhart, D.; Kaminsky, W.; Lovell, S.; Kovacs, J. A. Periodic trends within a series of fivecoordinate thiolate-ligated [MII(SMe2N4(tren) $)]+(\mathrm{M}=\mathrm{Mn}, \mathrm{Fe}, \mathrm{Co}, \mathrm{Ni}, \mathrm{Cu}, \mathrm{Zn})$ complexes, including a rare example of a stable CuII-thiolate. Inorg. Chem. 2007, 46, 9267.

(68) Coggins, M. K.; Sun, X.; Kwak, Y.; Solomon, E. I.; Rybak-Akimova, E. V.; Kovacs, J. A. Characterization of Metastable Intermediates Formed in the Reaction Between a Mn(II) Complex and Dioxygen, Including a Crystallographic Structure of a Binuclear Mn(III)-Peroxo Species. J. Am. Chem. Soc. 2013.

(69) Coggins, M. K.; Martin-Diaconescu, V.; DeBeer, S.; Kovacs, J. A. Correlation Between Structural, Spectroscopic, and Reactivity Properties Within a Series of Structurally Analogous Metastable Manganese(III),ÄìAlkylperoxo Complexes. J. Am. Chem. Soc. 2013, 135, 4260. 
(70) Coggins, M. K.; Kovacs, J. A. Structural and Spectroscopic Characterization of Metastable Thiolate-Ligated Manganese(III),ÄìAlkylperoxo Species. J. Am. Chem. Soc. 2011, 133, 12470.

(71) Lee, C.-M.; Chuo, C.-H.; Chen, C.-H.; Hu, C.-C.; Chiang, M.-H.; Tseng, Y.-J.; Hu, C.-H.; Lee, G.-H. Structural and Spectroscopic Characterization of a Monomeric Side-On Manganese(IV) Peroxo Complex. Angew. Chem. Int. Ed. 2012, 51, 5427.

(72) Krishnamurthy, D.; Kasper, G. D.; Namuswe, F.; Kerber, W. D.; Narducci Sarjeant, A. A.; Moenne-Loccoz, P.; Goldberg, D. P. A Low-Spin Alkylperoxo,àílron(III) Complex with Weak Fe,àíO and O,àíO Bonds:,Äâ Implications for the Mechanism of Superoxide Reductase. J. Am. Chem. Soc. 2006, 128, 14222.

(73) Namuswe, F.; Kasper, G. D.; Sarjeant, A. A. N.; Hayashi, T.; Krest, C. M.; Green, M. T.; Moenne-Loccoz, P.; Goldberg, D. P. Rational Tuning of the Thiolate Donor in Model Complexes of Superoxide Reductase: Direct Evidence for a trans Influence in FeIII,àíOOR Complexes. J. Am. Chem. Soc. 2008, 130, 14189.

(74) Brown, C. D.; Neidig, M. L.; Neibergall, M. B.; Lipscomb, J. D.; Solomon, E. I. VTVH-MCD and DFT studies of thiolate bonding to $\{\mathrm{FeNO}\}(7) /\{\mathrm{FeO} 2\}(8)$ complexes of isopenicillin $\mathrm{N}$ synthase: Substrate determination of oxidase versus oxygenase activity in nonheme Fe enzymes. J. Am. Chem. Soc. 2007, 129, 7427.

(75) Kitagawa, T.; Dey, A.; Lugo-Mas, P.; Benedict, J. B.; Kaminsky, W.; Solomon, E.; Kovacs, J. A. A Functional Model for the Cysteinate-Ligated Non-Heme Iron Enzyme Superoxide Reductase (SOR). J. Am. Chem. Soc. 2006, 128, 14448.

(76) Green, M. T.; Dawson, J. H.; Gray, H. B. Oxoiron(IV) in Chloroperoxidase Compound II Is Basic: Implications for P450 Chemistry. Science 2004, 304, 1653.

(77) Sallmann, M.; Siewert, I.; Fohlmeister, L.; Limberg, C.; Knispel, C. A Trispyrazolylborato Iron Cysteinato Complex as a Functional Model for the Cysteine Dioxygenase. Angew. Chem. Int. Ed. 2012, 51, 2234.

(78) Sallmann, M.; Kumar, S.; Chernev, P.; Nehrkorn, J.; Schnegg, A.; Kumar, D.; Dau, H.; Limberg, C.; de Visser, S. P. Structure and Mechanism Leading to Formation of the Cysteine Sulfinate Product Complex of a Biomimetic Cysteine Dioxygenase Model. Chem. Eur. J. 2015, 21, 7470.

(79) McQuilken, A. C.; Goldberg, D. P. Sulfur oxygenation in biomimetic nonheme iron-thiolate complexes. Dalton Trans. 2012, 41, 10883.

(80) McQuilken, A. C.; Jiang, Y.; Siegler, M. A.; Goldberg, D. P. Addition of Dioxygen to an N4S(thiolate) Iron(II) Cysteine Dioxygenase Model Gives a Structurally Characterized Sulfinato-Iron(II) Complex. J. Am. Chem. Soc. 2012, 134, 8758.

(81) McQuilken, A. C.; Matsumura, H.; Dürr, M.; Confer, A. M.; Sheckelton, J. P.; Siegler, M. A.; McQueen, T. M.; Ivanović-Burmazović, I.; Moënne-Loccoz, P.; Goldberg, D. P. Photoinitiated Reactivity of a Thiolate-Ligated, Spin-Crossover Nonheme $\{$ FeNO\} 7 Complex with Dioxygen. J. Am. Chem. Soc. 2016, 138, 3107.

(82) Shook, R. L.; Borovik, A. S. Role of the Secondary Coordination Sphere in Metal-Mediated Dioxygen Activation. Inorg. Chem. 2010, 49, 3646.

(83) Shook, R. L.; Borovik, A. S. The effects of hydrogen bonds on metalmediated 02 activation and related processes. Chem. Commun. 2008, 6095.

(84) Kobayashi, N.; Nevin, W. A. Electrocatalytic reduction of oxygen using water-soluble iron and cobalt phthalocyanines and porphyrins. Appl. Organomet. Chem. 1996, 10, 579.

(85) Soo, H. S.; Komor, A. C.; Iavarone, A. T.; Chang, C. J. A Hydrogen-Bond Facilitated Cycle for Oxygen Reduction by an Acid- and Base-Compatible Iron Platform. Inorg. Chem. 2009, 48, 10024. 
